\title{
Morphostratigraphy of the Sázava river terraces in the Bohemian Massif
}

\author{
BŘETISLAV BALATKA ${ }^{1}$, PHILIP GIBBARD ${ }^{2}$, JAN KALVODA ${ }^{1}$ \\ ${ }^{1}$ Charles University in Prague, Faculty of Science, Department of Physical Geography \\ and Geoecology \\ ${ }^{2}$ University of Cambridge, Department of Geography
}

\begin{abstract}
The results of geomorphological research into the Sázava river terraces are presented. This terrace system is characteristic by its variable structure which is conditioned by specific hydrodynamic processes that existed during the late Cenozoic evolution of the river valley. Two levels of Neogene fluvial sediments and seven Quaternary terrace accumulations along the Sázava course are distinguished. In the paper is also established their chronostratigraphical relation to the Vltava-Labe terrace systems.
\end{abstract}

Key words: fluvial terraces, Quaternary, Sázava river, Bohemian Massif

\section{Introduction}

River terraces originate in regions of variable tectonic uplifts combined with very specific climate-morphogenetic and hydrodynamic processes. Palaeogeographical history of the central part of the Bohemian Massif involved several morphogenetic events connected with significant tectonic uplifts. Strong uplift occurred during the Cadomian tectogenesis, weaker uplift also occurred in the Early Ordovician and this was followed by a very strong uplift in the Carboniferous. These uplift episodes were accompanied by denudation, which was particularly severe during the Early Variscan (Hercynian). The present denudation level was reached as late in the Late Palaeozoic, i.e. in Carboniferous (Malkovský 1975, 1979). Marine transgression penetrated the area of the future Central Bohemian Pluton during the Upper Proterozoic and the Lower Palaeozoic (Fig. 1).

During the Variscan period this area was affected by strong deep magmatism which caused faults and overthrusts and frequent Variscan intrusions. The Moldanubic area was dry land from Upper Permian to Lower Cretaceous and the Upper Cretaceous transgression affected only the NE margin of this area. This period of tectonic stability saw the development of planation surfaces. Lateritic and kaolinic weathering products were developing up to the beginning of the Oligocene, under warm and in some periods wet climate conditions. Up to the end of the Palaeogene, streams ran through shallow, wide vale-shaped low gradient valleys. 
The Sázava course and catchment were initiated during younger periods of the Neogene (Daneš 1913, Novák 1930, 1932). The main drives towards the Sázava drainage reunification were arch-like epeirogenetic uplift of the present watershed area between the Sázava and the Labe during the Upper Miocene to Pliocene. During the Pliocene, the Sázava flowed to the $\mathrm{W}$, in a large vale-shaped valley deepened into a tectonically and denudationally deformed Palaeogene planation surface, as well as into lower Neogene planation levels. In the late Cenozoic, free bends developed during the strong erosion which followed after the uplift of the Bohemian Massif. During the Quaternary, deepening of the ground plan of these valley bends did not change significantly. The typically developed incised meanders and bends were formed mostly in the Middle Pleistocene.

In this paper, substantial methodological aspects of our morphostratigraphical studies of the Sázava river terraces are based on:

1. the analysis of down-valley profile of the Sázava,

2. geomorphological and geological research of significant localities of fluvial sediments,

3. reconstruction of the terrace system in the down-valley profile and to the structure of the corresponding series of transverse profiles, and

4. cartographical processing of river terraces localities, Neogene sediments and planation surfaces (Balatka, Kalvoda 2009). Another methodological aspect of the geomorphological research into the Sázava river terrace system consists of qualitative changes in current morphostratigraphical approaches to the studying of natural phenomena during the late Cenozoic (e.g. Hughes 2007, Gibbard et al. 2009). The results of geomorphological research into the Sázava basin are therefore presented both with regard to possibility of using the main river terraces sediments for radiometric dating and in correlation with the chronostratigraphical system of the Vltava and Labe terraces.

The aim of the paper is presentation of the main results of morphostratigraphical research into the Sázava river terraces. The field geomorphological analysis has enabled a longitudinal profile of the fluvial terraces and Neogene sediment localities to be constructed (Balatka, Kalvoda 2008, 2010). The reconstruction method allowed two levels of Neogene fluvial sediments and seven Quaternary terrace accumulations (levels) along the Sázava course to be distinguished. It also allowed their chronostratigraphical relation to the Vltava-Labe terrace systems to be established.

\section{Geomorphological patterns of the Sázava valley}

The Sázava River rises as the Stržský potok Brook E from Nová Hư at $757 \mathrm{~m}$ a.s.1. This country forms part of the Žd'árské vrchy Hills in the Hornosvratecká vrchovina Highland. After its $225 \mathrm{~km}$ long course, the Sázava River empties into the Vltava in Davle (Fig. 1), where the water level is at $200 \mathrm{~m}$ (storage level of the Vrané dam), whereas the original level of the flowing river was at $196 \mathrm{~m}$ here. The Sázava drains a catchment area of $4,349 \mathrm{~km}^{2}$ (Photo 1). It flows through four units of the Českomoravská vrchovina Highland: the Hornosvratecká vrchovina Highland, the Křižanovská vrchovina Highland, the Hornosázavská pahorkatina Upland and the 
Křemešnická vrchovina Highland (Czudek et al. 1972). With the exception of its short source flow, from the Velké Dářko pound to Žd'ár nad Sázavou, the Sázava follows in a SE direction the course of tectonic depressions in a continuation of the Železné hory fault and of the so-called Dlouhá mez. In Žd'ár nad Sázavou the river changes its direction suddenly to W to WSW (but compare Fig. 1 with Photo 1) and from here it remains in the same direction to its confluence with the Vltava.

In the segment between Světlá nad Sázavou and the eastern neighbourhood of Ledeč nad Sázavou (Fig. 1), the river follows the S off-set of the Hornosázavská pahorkatina Upland, i.e. its subunit the Světelská pahorkatina Upland. The remaining segment of the course to Zruč nad Sázavou occurs in the Humpolecká vrchovina Highland, which is a subunit of the Křemešnická vrchovina Highland. The Humpolecká vrchovina Highland is dominated by the huge Mehelník horst bloc, which greatly participated in the evolution of the Sázava valley and the formation of the river terraces.

At Zruč nad Sázavou, the river enters the Středočeská pahorkatina Upland country, in which it remains as far as to its mouth (Sládek in Demek et al. 1987, Balatka and Sládek in Demek and Mackovčin et al. 2006). At first, as far as the Sázava town, the river crosses the marginal N-E part of the Vlašimská pahorkatina Upland unit, across its subunit the Mladovožická pahorkatina Upland. In this area, a longer segment of the Sázava changes the direction of its flow to N-W to $N$ (between the mouth of the Blanice and Sázava town); it follows the direction of the Blanická brázda Furrow tectonic structure and forms the most perfect valley meanders. Downstream of the mouth of the Želivka as far as to the mouth of the Blanice, the Sázava river takes the direction of the Želivka lower flow which is its major tributary. Near Sázava town, the river suddenly changes general direction towards the W (with shorter SW deviations) and it enters the relief of the Benešovská pahorkatina Upland unit. Among the shapedistinctive lower units (districts), the Divišovská vrchovina Highland and the Ondřejovská vrchovina Highland, are worthy of mention. Here the river formed a deep, closed valley, locally of trough-like character. In the segment further down to Kamenný Přívoz, in the lower and flatter relief of the Konopištská pahorkatina Upland, the valley occurs generally less incised and frequently even has a vale character; locally the valley has a clear two-stage evolution. A deep erosional valley of trough character was deepened by the river on its lowest course (between Kamenný Přívoz and Pikovice) in the hard rocks of the Jílovská vrchovina Highland.

In the segment from Havlíčkův Brod to Světlá nad Sázavou (river kilometres 164-145), the Sázava valley is mostly of the middle to shallowly incised into the slightly inclined denudational relief with plateaux inside the valley. It occurs at a relative height of $30-40 \mathrm{~m}$ above the floodplain. The highest planation surfaces occur up to $80 \mathrm{~m}$ above the floodplain (Photo 2). The valley mostly follows a SE-NW direction and, with the exception of the open valley bends between Havlíčkův Brod and Okrouhlice, its course is straight. Relatively sharp valley margins delimiting the extent of the Quaternary incision, are mostly situated at $425 \mathrm{~m}$ a.s.1., i.e. $20-35 \mathrm{~m}$ above the modern river level.

Segment from Světlá nad Sázavou to Ledeč nad Sázavou (river kilometres 145-129 is conspicuous by the valley changes its direction at first to the SW (at the mouth of the 
Sázavka) and then to the W. Locally migmatitised (to migmatites) biotitic and sillimanite-biotic paragneisses, predominate there, e.g. near Světlá nad Sázavou. Erlans, crystalline limestones (near Ledeč nad Sázavou), vein granites, etc. are relatively rare. These smaller bodies mostly transect the Sázava valley in a SW-NE direction. In the most resistant fine-grained biotitic-muscovitic granite, a pronounced valley bend (nearly a meander) of the Sázava was formed near Bilantova Lhota. Downstream of Smrčná, on the granites of the Melechov massif (Stvořidla), the river with a high level gradient crosses a trough-like valley, which is deepened into the upper parts of the Melechov (709 $\mathrm{m})$ and the Žebrákovský kopec Hill $(601 \mathrm{~m})$ by approximately $350 \mathrm{~m}$ or $220 \mathrm{~m}$. A distinctive valley bend $\mathrm{W}$ of Vilémovice was probably caused by occurrence of a more resistant vein granite and quartzite in the paragneisses. The valley has a relatively steep profile with its edge up to $70 \mathrm{~m}$ above the river level and, in two stages, it was incised some 115-140 $\mathrm{m}$ into the plateaux on Miocene sediments and into the highest planation surfaces.

The SE-NW valley segment from Ledeč nad Sázavou to Vlastějovice (river kilometres 129-112) is characterised by distinctive valley bends to meanders (near Vlastějovice, Fig. 2), the formation of which was probably caused by quartzite and amphibolite intrusions in paragneisses. The steep erosional slopes of the valley bends are up to $60-80 \mathrm{~m}$ high. The valley is deepened $110-135 \mathrm{~m}$ into plateaux on the Miocene sediments and 150-210 m into the highest planation surfaces. Downstream from Chřenovice, localities of low terraces occur in the convex parts of bends.

In the segment from Vlastějovice to mouthing of Želivka (Fig. 1, river kilometres 112-99), the generally ESE-WNW orientated valley is characterised by open bends (with the exception of a sharp meander downstream of Zruč nad Sázavou) and locally has a vale-like character. Here the valley incision into plateaux of Neogene sediments and planation surfaces is of 105-150 m. This segment represents the most remarkable part of the Sázava valley from the point of view of its evolution, because only here are there huge accumulations of Middle Pleistocene terraces, and also abandoned valley segments. The largely open valley has the character of a Neogene and Early Pleistocene valley basin.

The valley in the segment from the mouthing of the Želivka to the mouthing of the Blanice (river kilometres 99-79) follows the direction of the Želivka valley (SE-NW) and is characterized by open bends. These bends have high erosional slopes with rock outcrops and terraces (mainly near Kácov, Fig. 3). Higher planation surfaces are up to $140-183 \mathrm{~m}$ above the river; the present valley is mostly incised 60-80 $\mathrm{m}$ into plateaux surface and relics of the Neogene vale-shaped valley.

The Sázava valley in segment from the Blanice mouth to Sázava Town (river kilometres 79-57) follows a generally S-N direction, i.e. the direction of the Blanice valley, so that the river adapts itself to the course of the Blanická brázda Furrow. Between the mounth of the Blanice and Sázava town, there are frequent bodies of homogenous and laminated amphibolites in the Moldanubic gneisses. These more resistant rocks, mainly homogenous amphibolites, conditioned the formation of the most pronounced Sázava valley meanders. Between Rataje nad Sázavou and the town of Sázava, the most perfect incised meanders of the whole river course were formed, and with 90-140 $\mathrm{m}$ high rocky erosional slopes. The most pronounced meander near 
Př́ivlaky has a meander neck about a 200 m wide (Pilecká 1997). The formation of the valley meanders was probably conditioned by the frequent bodies of resistant amphibolites, into which the river was cut. With the exception of the Přivlaky meander, there are no higher river terraces. It shows that the meanders and bends were formed by rapid incision of the original free meanders during a strong erosional period in the Lower and Middle Pleistocene. Here the valley has a closed transverse profile and small relics of low terraces. Denudational plateaux of reduced dimensions in the proximity of the valley incision are situated 80-110 $\mathrm{m}$ above the river, and more distant watershed planation surfaces are situated at 150-180 m above the Sázava.

In the segment from Sázava to Týnec nad Sázavou (river kilometres 57-18, Fig. 4), the river markedly changes its valley direction from $\mathrm{N}$ to $\mathrm{W}$ (in the town of Sázava), with only the segment between Zlenice and Pořičí nad Sázavou being orientated towards the SW. The river here has formed open bends with a high curve radius and low terraces within the bends (in the Sázava, near Černé Budy, Zlenice, Poříčí nad Sázavou, Týnec nad Sázavou, Fig. 5). The NE neighbourhood of the town of Sázava contains localities of late Tertiary sediments at altitudes between 387 and $403 \mathrm{~m}$ (101 to $118 \mathrm{~m}$ above the river) which are situated at the margin of the right erosional slope of the meander. The Sázava - Labe watershed near Čekanov is at a distance of less than $3 \mathrm{~km}$ from the river. The valley margin in the observed segment is situated 70 to $85 \mathrm{~m}$ in a direct line above the river. The highest planation surfaces occur at 130 to $185 \mathrm{~m}$, their middle level is at $110-120 \mathrm{~m}$ and the lowest plateaux are 90 to $100 \mathrm{~m}$ above the river. The segment between Sázava and Hvězdonice almost lacks river terraces. Valley margins here on the few straight segments are situated 70 to $90 \mathrm{~m}$ above the river.

With the exception of the lowest course downstream from Pikovice (Fig. 1), the segment from Týnec nad Sázavou to the mouthing into the Vltava (river kilometres 18-0) has a significantly increased gradient. The valley is accompanied by terraces, mainly of higher levels, formed above the valley incision and indicating a pronounced divergence from the course. The isolated plateau localities are situated 90 to $120 \mathrm{~m}$ above the river. The valley incisions below the surface of a higher Middle Pleistocene terrace (IIIa) decline from $75 \mathrm{~m}$ in the confluence area to $55 \mathrm{~m}$ near Kamenný Újezd and to $40 \mathrm{~m}$ near Krhanice. Between Žampach and Pikovice in resistant rocks of the Jílové belt, the Sázava is cut in a closed to gorge-shaped valley with rock walls.

The down-valley profile of the stream, as the local erosional base for the tributary-valley evolution, is used as the base for reconstruction of the course of river terrace localities. The upper and part of the middle course (to Smrčná), between river kilometres 208.4 and 139.5 , in the length of $68.9 \mathrm{~km}$, is characterised by a gradual decrease of gradient, from $6.5 \%$ in Žd'ár nad Sázavou to $1.28 \%$ above Smrčná. The gradient curve has a markedly concave bowed shape in this section, with an anomaly beneath the confluence of the Sázavka, where a slight diminution and consequently an increase of the level gradient are visible. The generally regular shape of this gradient curve corresponds (together with the water content of the stream) on the relatively homogenous petrographical composition of the rock substrate, where Moldanubic gneisses to migmatites predominate and granites of Moldanubic pluton are scarcer. 
Between the villages of Smrčná and Vilémovice, between river kilometres 139.5 and 135.4, a prominent flexure of the gradient curve occurs, where in a segment of $4.1 \mathrm{~km}$ the river markedly increases its gradient of $5.72 \%$. This gradient step was caused by more resistant granite of the Melechov massif. This granite massif, together with neotectonic uplift, supressed a retrogressive erosion wave progressing against the flow of the Sázava. Active water erosion is also proved by erosional forms on granite blocks in the riverbed (Balatka and Sládek 1977).

Downstream from the bend, between Vilémovice (river kilometre 135.4) and Podělusy (river kilometre 17.9), the Sázava has a remarkably regular gradient level in a $117.5 \mathrm{~km}$ segment which, even after a substantial increase of discharge of the main river by the water of the Želivka and the Blanice, does not give rise to any significant change. It is remarkable that more resistant rocks in Moldanubic gneisses (amphibolites, hornbland, quartzites and crystallic limestones) have influenced the geomorphological character and the course of the valley more than its gradient conditions. The gradient curve is quite straight and the mean gradient in this long segment is only $0.88 \%$. Slight anomalies of the gradient are due to weirs which change the gradient of the course locally in short segments. Local increases of the gradient are also seen mainly in the concave parts of valley bends and meanders (in short segments even exceeding 3\%o, and in other places only up to $0.5 \%$ ). In a longer segment downstream Ledeč nad Sázavou $(4.7 \mathrm{~km})$ there is only a minor increase of the gradient $(1.45 \%$ ). This long segment of the middle course is situated, in reference to the level of the near Vltava, in a markedly hanging position.

The second gradient step (bend) is represented by the long-profile in the lower Sázava course between Podělusy and Pikovice. Here in a $12.9 \mathrm{~km}$ long segment (between river kilometres 17.9 and 5.0), the river has a mean gradient of $3.90 \%$. This gradient anomaly has been conditioned by retrogressive erosion progressing upstream from the mouth to the Vltava which was retarded by resistant rocks of the Jílové belt and by granitoids of the Central Bohemian pluton. The present fluvial erosion is also documented by occurrences of rock-cut basins in the riverbed near Krhanice (Balatka and Sládek 1977).

The last segment of a different level gradient is in the lowest course in a $5.0 \mathrm{~km}$ long segment upstream the confluence with the Vltava. The major part of this reach is situated at the end of the high water level of the Vraný water basin, so that the mean gradient of the river level here is only $0.35 \%$. The original level gradient, before construction of the waterworks was on average about $1.0 \%$. In its lowest course, the river passes through less weathering resistant siltstones, slates and greywackes mainly of the Upper Proterozoic Š ̌̌chovice group.

\section{Tertiary sediments and Quaternary terraces of the middle and lower Sázava}

Neogene sediments are preserved in two areas of the Sázava river region: (1) in the neighbourhood of Ledeč nad Sázavou and Zruč nad Sázavou, (2) near the town of Sázava. These sediments are classified as Neogene based on their relative height above 
the valley floor and because the sediments differ in form and petrographical composition from Quaternary terrace aggradations. On the Sázava-Želivka interfluve, i.e. between the NW foot of the extensive Melechov ridge $(709 \mathrm{~m})$ and the confluence of both rivers, several Neogene fluvio-lacustrine sediment localities have been preserved. This is a lower large planation surface, the height of which is locally linked to those of Neogene sediments. The planation surface in the watershed area slightly decreases from SE to NW, from 470-486 $\mathrm{m}$ to 390-400 $\mathrm{m}$ at the confluence of both rivers. The Neogene deposits are probably denuded relics of an originally larger fluvio-lacustrine basin. This system formed a shallow tectonic depression stepwise incised into the neighbouring higher ground. The present planation surface, which almost lacks elevations such as knobs and outliers (an exception is Luha $498 \mathrm{~m}$ near Nová Ves u Dolních Kralovic), is probably of Upper Miocene age. Tertiary sediments are covered by up to $2 \mathrm{~m}$ thick sandy-clayey loams almost everywhere.

The most SE situated outlier of Neogene sediments is near Bojiště the highest surface of which is at 486 m (135 m above the Sázava level near Ledeč nad Sázavou). The locality is aligned from SW to NE and probably represents the remnant of the filling of the Želivka bed orientated towards the Sázava. Deposits are formed of loamy to clayey sands with gravels and gravely sands with isolated small intercalations of light grey sandy clays. These Neogene sediments were found as the filling of a shallow basin (bed) of a thickness of 2.2-12.4 $\mathrm{m}$ with their base at 471-481 m.

The locality, situated N of Kožlí, is cut in a S-N direct through the Sázava-Želivka watershed. It is a filled by a bed 200-400 m wide with its surface at 452-466 m and with a paragneiss bedrock at 442-451 m. The thickness of loamy and clayey sands with gravels and clay (at the base of loamy and clayey gravels) reaches a maximum of 10-14 $\mathrm{m}$ in borings (Král 1971). In the E neighbourhood of the locality there is a higher planation surface at $480 \mathrm{~m}$. Near Přemelovsko with its surface at 448-467 m the locality has a low stratum $(1 \mathrm{~m})$ of clayey-sandy loam in its basal part (Rybařik 1968), but no borings were undertaken in the higher surface. Conversely, a boring that reached the base of loamy sands and sandy clays $6.5 \mathrm{~m}$ thick was confirmed at the Zahájí locality at the $443 \mathrm{~m}$ spot height (surface at $449.50 \mathrm{~m}$, Rybařík 1968).

The most extensive occurrence of Neogene sediments NE of Všebořice, where the surface at 428-452 m, was confirmed by a boring here $2.7 \mathrm{~m}$ thick loamy sands with quartz cobbles and underlying sandy clays resting on paragneiss eluvium at $435.3 \mathrm{~m}$ was found (Rybařík 1968). A smaller locality above the left erosional slope of the Sázava valley bend SW, from the Chřenovice railway station shows a $2.3 \mathrm{~m}$ thick cover of sandy loams with cobbles and of sandy-clayey gravels at its base at $442.2 \mathrm{~m}$. An elongated narrow ridge locality near Čejtice and Onšovec is covered by only 2.0-3.5 m thick sandy-clayey loams with cobbles and loamy-sandy gravels with their bases at 433-437 $\mathrm{m}$ and their surface at 435.0-440.5 m.

Between Havlíčkův Brod and Světlá nad Sázavou, there several localities of sandy clays and loamy sands with quartz cobbles 1-2 $\mathrm{m}$ thick were distinguished and classified as Neogene (Hrubeš 1995). They occur 70-80 m above the river. These deposits are mainly the occurrences at the Vadínský kopec Hill (470 m), near Nová Ves u Světlé nad Sázavou (471 m) and S from Závidkovice (467 m), considered by Novák (1932) as river terraces. 
Another region with relics of Neogene fluvial-lacustrine sediments is NE of Sázava in the greater area of the Sázava-Labe watershed. Here, sands and gravelly sands of unknown thickness (probably up to $10 \mathrm{~m}$ ) have a surface covered by loess loams, situated mostly at 397-403 m (near Radvanice, Újezdec, Chrastná), i.e. 112-118 m above the Sázava level close by. They probably represent denudational relics of deposits of the so-called Nechybská řeka River which flowed in the direction of the Blanice (and the Blanická brázda Furrow) through a tectonic depression in an outcrop of Upper Cretaceous sediments to the $\mathrm{N}$ on the Kouřimská tabule Table during the Neogene. From here it flowed to the area of the present Labe (Polabí) Basin (Daneš 1913, Novák 1932). Malkovský $(1975,1979)$ has a different opinion on the direction of drainage. He assumes that these are sediments of a Lower Miocene north-side affluent of the Neogene Sázava.

The stratigraphical classification of the locality between Radvanice and Nechyba is problematic because it is here slightly inclined to the $S$, i.e. to the edge of a steep erosional slope of a Sázava meander. The surface of this plateau (374-387 m a.s.1., or 88-101 $\mathrm{m}$ above the river) is overlain by a thin stratum of subangular cobbles and quartz debris and occasionally also of granite. On the $\mathrm{N}$ part of the plateau, there are local outcrops of yellowish grey to rust-coloured clays with fragments of quartz; this is probably a fossil (?) weathered amphibolite rock. Further to the N, the sediments are buried by a layer of loess loam of 5-6 m thick near the former Radvanice claypit. Based on its considerable relative height, the character of sediments and the position in the longitudinal profile, this occurrence can be considered as Neogene level B.

The morphostructural depression $\mathrm{E}$ of the slope on the Kouřim fault with relics of Bílá Hora and Peruc Upper Cretaceous groups of strata is inclined towards the $\mathrm{N}$ and crossed by the Vavřinec Brook. Fluvial sandy gravels at the $\mathrm{N}$ margin of Kouřim present at about $12 \mathrm{~km}$ from the Neogene sediments in the Sázava-Labe watershed, are classified as Middle Pleistocene on the geological map 1 : 50 000, sheet 13-31 Říčany. Further to the N, relics of older aggradations of the Kouřimka river link to an extensive locality of the Labe terrace IIIa sediments on the Kourrimská tabule Plateau. These sediments correspond stratigraphically to the Mindel 1 stage of Balatka et al. (1966).

During borings and excavations made for the construction of Želivka feeder canal and of a water reservoir near Jesenice, Neogene fluvial sediments were found in the 1960s in a remarkable position on the watershed between the Zahořanský potok Brook and the Botič, i.e. not far from the Sázava-Vltava watershed. Between Horní Jirčany and Jesenice, sands and clayey sands with gravels and clay layers were found. The sediments reached a thickness of more than $30 \mathrm{~m}$ and up to $450 \mathrm{~m}$ wide and in $40 \mathrm{~m}$ deep beds (Kleček et al. 2001). The planation surface with a thick covering of loess and slope sediments is situated mostly at 350-380 $\mathrm{m}$ a.s.l., i.e. $145-175 \mathrm{~m}$ above the Sázava at 11-12 km from Luka pod Medníkem.

Close to the confluence of the Sázava and the Vltava there are the classical localities of Central Bohemian Neogene sediments near Sloup (surface at $320 \mathrm{~m}$ ) and near Klínec $(363 \mathrm{~m})$. The sediments near Klínec at the Vltava-Berounka watershed were assigned on the basis of palaeobotanical evidence to the Lower Miocene (Mašek et al. 1984). 
Denudational relics of Neogene (probably mostly Miocene) sediments are found in two areas of a planation surface, i.e. in morphostructural depressions of the Sázava-Želivka interfluve and the Sázava-Labe watershed. They both represent relics of accumulation fillings of old riverbeds and denudation relics of regional cover. They are fluvial to fluvial-lacustrine deposits, about $10 \mathrm{~m}$ thick, situated clearly above the Quaternary valley which cuts through their surface at $110-135 \mathrm{~m}$ above the river (prevailing level A). Their current occurrences indicate either that the Sázava drained from the town of the same name to the $\mathrm{N}$ (according to Novák 1932b) or, according to Malkovský $(1975,1979)$, they represent Neogene drainage towards the W. Different absolute heights of Neogene localities in the Sázava-Želivka interfluve (to an extent of about $20 \mathrm{~m}$ ) may show, if the sediments are of the same age, evidence of slight tectonic disruption. They are therefore of Pliocene age. According to the new chronostratigraphical scheme (Table 1), they may indeed already be already Early Pleistocene sediments (see also Kodym et al. 1993, Müller et al. 1993). Neogene sediments near Jesenice which are near the Sázava-Vltava watershed may be relics of the drainage of the lower Sázava catchment to the N. Considerable uplift above the Sázava level, reaching as much as $175 \mathrm{~m}$, could possibly be explained by a slight anticlinal folding of the ground of the present watershed above the syncline depression in the place of the Sázava valley.

Reconstruction of terrace localities in the long profile has enabled the determination of the terrace system and allowed then to be equated to those of the Vltava system. The Sázava system includes seven terrace accumulations that correspond to analogous levels of the main river, the Vltava. The reconstruction method helps recognition of a terrace system (Table 1) comprising seven levels including, on the one hand independent terraces, and on the other hand groups of terraces. The terraces are differentiated using Roman numerals I to VII, where level I is the oldest and the level VII the youngest. Small letters a, b express appurtenance to a group, i.e. a is higher level, b lower level of either independent or combined (erosion-accumulation) genesis.

\section{Group I terraces}

The eroded remnant of river gravels at Světlá nad Sázavou (near cemetery) at about 420 m a.s.l. (32 m above the Sázava level, Hrubeš 1995) probably belongs to the oldest Pleistocene terrace above the Smrčno trough. Isolated higher-situated localities with subangular cobbles, together with prevailing debris are mentioned by Novák (1932) as terraces near Závidkovice and Vadín at 467-470 m (70-75 m above the river) but they are now considered as to be of Neogene age (Hrubeš 1995). The reason for this time classification, besides the relative high altitude, is also the character of the sediments, which are clayey and loamy sands with quartz peebles.

Sázava terrace Ia which is overlain by accumulation cover was confirmed in several borings on the left bank of the Sázava river near Střechov (Photo 3), e.g. in the bend of the D1 highway from a NE to the SE direction (Passer 1967b). The surface of clayey sands with gravels is situated at $378 \mathrm{~m}$ (62 m above the river level), its base (eluvium of paragneiss) was not found even at a depth of $7 \mathrm{~m}$, but is presumed to occur at $370 \mathrm{~m}$ a.s.l. This distinctive locality gives the highest terrace level its name, the Střechov unit (Ia). 
Occurrences of terrace I are only preserved sporadically (Photo 3), so that the long profile course of this terrace in the Sázava valley cannot be reliably reconstructed. Besides localities with a 5-8 m thick accumulation cover (e.g. Fig. 3), only denudation relics with poorly rounded gravels are preserved. The occurrences at the highest level (level Ia), i.e. with their surfaces at about $60 \mathrm{~m}$ above the river, can be linked to the Vltava Lysolaje Terrace Ia, or IA (Záruba-Pfeffermann 1943, Záruba et al. 1977). Besides this level in the Sázava valley, there are lower mainly denudation relics (at 47-52 $\mathrm{m}$ of relative height) probably corresponding to the Suchdol Terrace of the Vltava (Ib, Záruba-Pfeffermann 1943, or IB, Záruba et al. 1977).

\section{Terrace II (Český Šternberk)}

This terrace level has been preserved relatively rarely in the Sázava valley, and even then only in limited areas. The most upstream occurrence of terrace II is a small plateau above the railway station, SW of Vilémovice. This is an eroded relic with its surface at about $35 \mathrm{~m}$ above the river level. Frequent gravels mostly to up to $10 \mathrm{~cm}$ in diameter descend down a mild slope to a relative height of $28-30 \mathrm{~m}$ above the river. The deposits are probably not thicker than 2-3 $\mathrm{m}$. Another locality of terrace II is a pronounced plateau with cobbles on the right Sázava bank SE of Ledeč nad Sázavou, $\mathrm{S}$ from the road to Ostrov. On its surface, at $386 \mathrm{~m}$ a.s.1. (35 $\mathrm{m}$ above the Sázava level), frequently occur gravels up to $15 \mathrm{~cm}$ in diameter, composed of quartz, quartzites, granites and gneisses with obvious traces of aeolian corrasion.

The most important locality for terrace II is preserved within an open valley bend of the Sázava near a settlement of holiday house $1 \mathrm{~km}$ NE of Český Šternberk (Fig. 3). Here dark rusty brown gravelly sands, with small pebble and coarse-grained clayey sands, are chaotically deposited and strongly cemented. Besides quartzes, poorly rounded cobbles by crystalline complex rocks (mainly paragneisses) of a relatively fresh aspect often also occur. In the lower part of the hollow the sediments are uncemented and little weathered. A very slightly inclined small plateau with its surface at 338-340 m a.s.l. overlain by a thin layer of deluvial deposits is situated $37-39 \mathrm{~m}$ above the Sázava level. The lowest occurrence of the terrace sediments at $323 \mathrm{~m}$ a.s.l. are $22 \mathrm{~m}$ above the river.

Terrace II has been reconstructed only in the segment between the neighbourhood of Ledeč nad Sázavou and Hvězdonice on the basis of several localities in the Sázava valley. The surface of the terrace parallels the river course, and occurs at relative heights of $35 \mathrm{~m}$ near Vilémovice and 37-39 m near Český Šternberk. The Sázava terrace described corresponds to the Vltava Pankrác Terrace, i.e. to level Ib (ZárubaPfeffermann 1943), or step II (Záruba et al. 1977). Its surface in the confluence area is situated $87 \mathrm{~m}$ above the original (undammed) level.

\section{Terrace group III}

Based on the thickness of its sediments, terrace group III represents, in the genesis and evolution of the valley, the most important link in the Sázava terrace system (Photos 4 and 5). Its origin and structure were largely influenced by a pronounced step 
in the river gradient in the area of the Melechov granite massif downstream of Světlá nad Sázavou. This step was formed during a strong erosional event that followed accumulation of of terrace II, when the river had deepened its bed in its middle course by about $35 \mathrm{~m}$. The front of the regressional erosion progressing upstream was retained by the huge uplifting barrier of the granite massif mentioned above. A thick accumulation of fluvial sediments occurred in the downstream segment of the Melechov step. After reaching the highest level of sediments of the terrace surface the river had practically compensated for this gradient step change. Therefore, following the end of the accumulation stage, the river gradient again approached an equilibrium profile. Thick accumulations of terrace III aggradation have been preserved thanks to the fact that the river, after having reached the highest aggradation level, had progressively transferred its course to its present direction. This ensured that the accumulation fillings of abandoned valleys remained unaffected by younger erosion of the river.

The first locality of terrace IIIa (Chabeřice) is situated on the right bank of the Sázava, $2 \mathrm{~km}$ SE of Ledeč nad Sázavou (river kilometre 131). Here a small plateau at the slope edge at 375-380 m a.s.l. (24-29 $\mathrm{m}$ above the river level) is covered by gravels up to $15 \mathrm{~cm}$ a diameter, mostly of quartz and quartzite, with less granite and gneiss. Here poorly rounded gravels have mainly been rounded with imperfect edges by wind activity. In a $2.5 \mathrm{~m}$ deep excavation, clayey sands with tiny layers of gravel, with occasional small cobbles, were discovered.

Very thick accumulations of terrace III aggradations have been preserved in the Březina W from Vlastějovice segment (Fig. 2) and the NW neighbourhood of the Želivka mouth, i.e. between river kilometres 112 and 97. The plateau with quartz and gneiss gravels on the right river bank NW of Březina reaches $360.5 \mathrm{~m}$ (military topographical map $1: 25000$ ), or at $363 \mathrm{~m}$ (basic map $1: 10000$ ), i.e. 30 or $32.5 \mathrm{~m}$ above the river level. A remarkable locality where sediments of terrace III occur on the river's left bank, E of the railway station at Horka nad Sázavou. In borings, terrace sediments 15-16.5 m thick were found, the surface of which occurs at $345 \mathrm{~m}$ and their base is at 335-327 m (Rybařík 1968). These surfaces correspond to terrace III situated at 22-17 $\mathrm{m}$ above the original (undammed) river level. This accumulation comprised medium coarsed to coarse-grained sands (slightly loamy in the upper parts) with a low content of small quartz, paragneiss and granite cobbles (in the lower position where gravel was more frequent). At its base a $1.3 \mathrm{~m}$ thick position of medium coarse to coarse sandy gravels overlaid paragneiss and amphibolite (Rybařík 1968).

The thick sediments near the Horka nad Sázavou railway station filled the former bow-shaped riverbed (furrow) reaching a width of up to $150 \mathrm{~m}$. This is curved towards the NE. In the transverse profile, the riverbed was visibly asymmetrical, with a steep right concussion slope inclined up to $60^{\circ}$ and with the lowest position of the base at its foothill. The sedimentary filling of the bed has been largely preserved, because the bed from the time of terrace III was separated from the younger valley (including the present one) by a ridge partition formed of resistant amphibolite and paragneiss. This occurrence of Pleistocene sediments represents the remnant of a thick terrace accumulation that abuts a steep right valley slope (greater than $60^{\circ}$ ), and that in the $\mathrm{W}$, in the place of the erosional slope of the former river bend orientated in a curve to the $\mathrm{S}$. 
Another locality important for the genesis and reconstruction of the terrace system is situated on the left bank of the Sázava near the settlement of Buda (Photo 5). This is a very short section of abandoned valley of the Pleistocene Sázava, separated from the present valley by the amphibolite monadnock of Horka (363 m). A visibly lowered former surface of fluvial sediments $(344-350 \mathrm{~m})$ corresponds to that of terrace III (Buda). Here the surface of the terrace sediments is mostly at 345-348 m (the lowest being $339 \mathrm{~m}$, the highest $350.5 \mathrm{~m}$ ), its base (on weathered paragneisses and amphibolite) is found in the lowest position at 327-330 m and in a higher level at 340-344 m. The original undammed level of the Sázava is situated here at $327 \mathrm{~m}$ a.s.l. The terrace sediments here are formed mostly by sands $(65-81 \%)$, less by gravels (16-30\%), clays and silts form $3-5 \%$ of the mass of the sediment. These sands are composed mainly of quartz grains, rock debris, feldspar and mica. Moreover, at the base of these sediments a position of middle coarse to coarse sandy gravel was found (Photo 5). The maximum thickness of sediments, determed from borings, was 17-20.5 m.

The best recorded locality of the terrace III sediments is the abandoned valley segment on the left riverbank S of Zruč nad Sázavou (Photo 4). Here a geomorphological position of this site: a fossil depression less than $1 \mathrm{~km}$ long and 200-300 m wide, follows in a curved course a steep erosional slope of the Sázava valley bend. The lowest positions of the gneiss substrate beneath the terrace sediments were discovered using borings (Rybařík 1968) at 329.75 and $329 \mathrm{~m}$ (4-5 m above the Sázava level). These heights occur in pronounced depression 50-70 $\mathrm{m}$ wide and 5-7 $\mathrm{m}$ deep, excavated into a higher level at 335-337 m. From the lowest places of this re-deepened bed the base of the terrace rises continually in the opposite direction, i.e. towards the margin of the left slope of the Sázava valley. The surface of terrace aggradations was situated at a maximum along the $356 \mathrm{~m}$ contour line, and it was covered along the left slope by a slope of sandy loams up to $8 \mathrm{~m}$ thick. In the highest position $(365.2 \mathrm{~m}) 15.8 \mathrm{~m}$ thick sands lay at $349.4 \mathrm{~m}$ a.s.l. on granite eluvium was recorded (Král 1969, Václavek 1970). They probably form relics of terrace II aggradations; at the level of the maximum accumulation terrace, sand has reached the level of the present narrow gneiss ridge on the left slope of the Sázava valley. Here a small valley of a right affluent of the Sázava used to be situated, into which this river had transferred initially from the Domahoř valley (from the level of the terrace IIIa surface). Later, at the time of formation of terrace IIIb, the Sázava left the valley near Buda.

Terrace sediments of the Domahor valley were formed, according to sedimentological analyses, mostly by sands representing about $60-80 \%$ of the total mass of deposits, by gravels $13 \%$, clays and silts $7 \%$. Medium-coarse sands $(64 \%)$ predominated over the coarse-grained $(10 \%)$ and fine ones $(6 \%)$. They were composed mostly of quartz (44-83\%), mica, feldspars and granites. The sandy gravels are mostly composed of quartz (38-52\%) and gneisses (37-45\%), granites (5-16\%), feldspars (2-5\%), ironstones, pegmatites and amphibolites (Rybář 1958, Král 1969, Hušner 1970, Václavek 1970). The greatest thickness of the terrace deposits is $28.7 \mathrm{~m}$, with their surface at $358.45 \mathrm{~m}$ and their base at $329.75 \mathrm{~m}$.

Both levels of the terrace group III are preserved on the left riverbank near the eastern margin of Zruč nad Sázavou (Photo 4). These terrace sediments were 
penetrated by numerous borings (Štěrba 1976): terrace IIIa has its maximally surface on the plateau at the spot height of $355 \mathrm{~m}$, and its reduced surface in a built-up area in the NW neighbourhood is situated at 340-346 m (terrace IIIb). At up to $14 \mathrm{~m}$ thick, mostly medium-grained sands (locally clayey) with gravel, at the bottom with coarser gravels, rest on paragneiss at a maximum height of 330-332 m.

The most extensive and geomorphologically most pronounced segment of the abandoned Sázava valley is a depression near Chabeřice, NE of the present valley between river kilometres 100 and 94 . This depression is separated from the present Sázava valley near the mouth of the Želivka (river kilometre 98.9) by gneiss ridges with summits reaching $375 \mathrm{~m}$ and $381 \mathrm{~m}$, and with steep rock slopes falling to the Sázava floodplain. The abandoned valley has a significantly straighter and shorter course (3 km long) than the present Sázava course $(6 \mathrm{~km})$. The valley watershed near the Chabeřice railway station at $347 \mathrm{~m}$ (28 m above the Sázava level) is situated in a slightly reduced position, against the presumed surface of a terrace IIIa. The highest recorded position of these sediments was 350-351.5 m W of Chabeřice, and their greatest thickness is $25.7 \mathrm{~m}$. The paragneiss substrate beneath the river deposits was found at 322-325 m (i.e. 3-6 m above the Sázava level, Kůta 1956), in the SE part of the locality between Čížov and Chabeřice. The base of sediments is asymmetrical in the transverse profile and its lowest places follow the concave part of the re-deepened depression. The coarse-grained clayey sands contain layers of gravelly sands with cobbles (mostly subangular) and debris of quartz, quartzite, paragneiss, granite, aplite and pegmatite and occassionally amphibolite. The gravels are generally $4-8 \mathrm{~cm}$ in diameter, but reach a maximum of $12-15 \mathrm{~cm}$. The large quartz and quartzite cobbles had rounded edges.

The valley watershed NW of Čížov at 340-341 m (23-24 m above the Sázava level), corresponds to the surface of terrace IIIb. The transverse profile of the Chabeřice valley is shaped as an open vale depression deepened 30-50 m into the level of pronounced plateaux (relics of valley pediment?) in the $\mathrm{N}$ neighbourhood $(380-400 \mathrm{~m})$. These plateaux are situated slightly above the presumed surface of the oldest Quaternary terrace (I) that probably originated at the end of the Pliocene, i.e. before the deepening of the Sázava valley. The undulated surface of the watershed ridge is situated at $450-470 \mathrm{~m}$ and has partial elevations and relics of an older planation surface. The gneiss ridges, separating the Chabeřice valley from the present Sázava valley at 360-381 m, are situated only some $20-30 \mathrm{~m}$ above the abandoned valley.

At the level of the terrace IIIa surface, fluvial sediments were found near the SW margin of Kácov (Čihák and Šilhan 1988) where their surface was at $341 \mathrm{~m}$ (29 m above the Sázava level) and their base was at $338.5 \mathrm{~m}$, or lower than $336 \mathrm{~m}$ (Fig. 3). Additionally in the core of a huge valley meander in which the town of Sázava is situated, the river changes its direction from generally $\mathrm{N}$ to continuously $\mathrm{W}$. Here a small locality of terrace IIIb, E of the railway station with its surface at 305-306 m (31-32 $\mathrm{m}$ above the river level), and its base at $297 \mathrm{~m}$, was recorded. This surface is covered by up to $8 \mathrm{~m}$ thick loamy sands with tiny cobbles and gneiss debris.

Sediments of terrace IIIa were found by borings on the left Sázava bank near Hvězdonice, ESE of the railway station (Passer 1967b), where their surface is at 
306-307 $\mathrm{m}$ (32-33 $\mathrm{m}$ above the river). A reduced surface at 303-305 m, with its base at $300 \mathrm{~m}$, corresponds to terrace IIIb. Fine-grained (at the base medium-grained) sands with gravel $(2-5 \mathrm{~cm}$, at the base $10-25 \mathrm{~cm})$ were found in borings there. Imperfectly rounded cobbles in this sediment were formed mostly of quartz, less of granite, pegmatite and metabasites.

Another important locality of terrace IIIa is a plateau near Kamenný Újezdec, between river kilometres 13.0 and 11.0. Here, its surface is covered by frequent gravels and it slightly rises to the NW from $274 \mathrm{~m}$ up to $280 \mathrm{~m}$ (55 m above the river). Sandy gravels overlie deluvial sandy loams at a gradient of $3-5^{\circ}$ up to the $290 \mathrm{~m}$ contour. The Kamenný Újezdec Terrace is situated above the valley cutting in the segment where the Sázava level gradient increases.

After an interruption in the trough-shaped valley below the Medník (416 m), terrace IIIa is developed in eroded relics above the edge of the steep right bank from Pikovice down to the confluence with the Vltava. Small plateaux between gorges above Petrov u Prahy railway station have their surface at $275 \mathrm{~m}$ (74 m above the undammed level) and their sandy gravels are mostly 2-3 m thick. Only NW of the railway station do they appear at $265 \mathrm{~m}$ a.s.l. on the valley slope the underlain by Proterozoic slates.

A markedly denuded locality of terrace gravels of terrace III about $1 \mathrm{~km} \mathrm{E}$ of the Sázava mouth is situated at $268-273 \mathrm{~m}$ and its $\mathrm{N}$ continuation along the road from Sázava town to Petrov has its surface at $272 \mathrm{~m}$ (76 m above the original undammed level) and its base at about $269 \mathrm{~m}$. The gravels (up to $20 \mathrm{~cm}$ in diameter) are composed mainly of quartz, granitoids and rocks of the Jílové belt; on the surface, also frequent debris of underlying slates locally appear. The relief above the valley edge with occurrences of terrace IIIa is a valley pediment with a markedly concave slope below the hills W of Petrov. These localities near the Vltava of the Sázava terrace IIIa are related to the Kralupy Terrace (Ib, Záruba-Pfeffermann 1943, or IIIA, Záruba et al. 1977).

In the Sázava valley downstream of the Smrčno gradient step, extraordinarily thick accumulations of sediments of terrace IIIa were formed (Chabeřice, up to $25 \mathrm{~m}$ ). Here their entire thickness is preserved in shorter abandoned valley segments as a result of relocation of the bed in the highest level of accumulation. In aggradations of this Chaberrice Terrace, a lower or intercalated terrace IIIb (Budy) was formed, with its surface about $8 \mathrm{~m}$ lower than that of the main terrace (about $30 \mathrm{~m}$ above the river level).

In the lowermost Sázava course, a terrace III is preserved above the valley cutting in the segment of the increased level gradient. The surface of step IIIa largely diverges downstream from about $30 \mathrm{~m}$ at the beginning of the gradient step to $75 \mathrm{~m}$ in the confluence area. Whereas the surface of the terrace shows a regular and slight gradient, its base at the lower course probably had an increased gradient which has been progressively levelled by the accumulation progressing from the Vltava valley. Presumably the accumulation of sediments filled the pre-deepened trough to greatest thicknesses at the site of the present valley and that this filling was removed during the subsequent erosional stage.

In the confluence area, the Sázava Terrace IIIa progressively merges into the Kralupy Terrace of the Vltava (Ib, Záruba-Pfeffermann 1943 or IIIA, Záruba et al. 
1977). The only occurrence of a Sázava terrace IIIb, with a thick cover of sediments at the confluence with the Vltava, is classified in the Vltava terrace system as the Vinohrady Terrace (IIa, Záruba-Pfeffermann 1943 or IIIB, Záruba et al. 1977). At several localities of the Vltava terrace system (including the Berounka) and the Labe a unified accumulation of both these terraces has been demonstrated, i.e. similarly as in the middle Sázava course.

\section{Terrace IV (Týnec)}

Terrace IV developments in the Sázava valley cutting are distinguished in isolated relics in the reach between the neighbourhood of Ledeč nad Sázavou and Kamenný Přívoz (between river kilometres 125 and 12). The first occurrence of this terrace is a degraded remnant of gravels in the core of a meander bend, situated $3 \mathrm{~km} \mathrm{WNW}$ of Ledeč nad Sázavou. Here its surface is at about $12 \mathrm{~m}$ above the river level.

A marked locality of terrace IV occurs in Kácov (Fig. 3), where it forms a marked slope towards the river. This perfect terrace landform has its surface at $322-327 \mathrm{~m}$ (11-16 $\mathrm{m}$ above the river) and its base on paragneiss was encountred in numerous borings

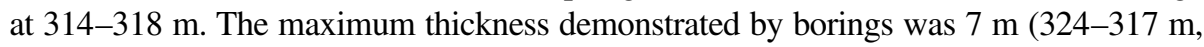
Hašlar 1959, Passer 1967b and others). In a $2 \mathrm{~m}$ deep trench near the school (about $226 \mathrm{~m}$ ), coarse-grained and medium coarse loamy sands, with dispersed gravels of granites and gneisses, were found in 2001. The surface of the terrace plateau merges in a concave profile of pediment type into a higher slope on paragneiss. The relic of deposits of a terrace IV is also preserved in the river meander in the town of Sázava (Fig. 3), E of the railway station (river kilometre 56) where the surface of this terrace is situated at $300-302 \mathrm{~m}(15-17 \mathrm{~m}$ above the river) and its base is at $297 \mathrm{~m}$.

The geomorphologically marked plateau is covered by gravelly sands of terrace IV that are 3-4 m thick in the inner part of a valley river bend in Týnec nad Sázavou. The surface at $273 \mathrm{~m}$ is $19 \mathrm{~m}$ above the river level; the granodiorite to tonalite base was proved in borings at $269 \mathrm{~m}$. In the segment of an increased river level gradient downstream Týnec nad Sázavou, only isolated small denudation relics of sediments of terrace IV were found.

In the reconstructed long profile, Sázava terrace IV runs roughly parallel to the present river level, i.e. with its surface at $15-20 \mathrm{~m}$ and its base mostly $10-15 \mathrm{~m}$ above the river. Because of its relationship to the Vltava Letná Terrace (IIb, Záruba-Pfeffermann 1943 or IV, Záruba et al. 1977), in the segment of the gradient step of the lowest course, its reconstructed course displays a pronounced divergence (by $35 \mathrm{~m}$ in $20 \mathrm{~km}$ ) in the opposite direction. It results in the surface of the Letná Terrace being situated about $55 \mathrm{~m}$ above the undammed Vltava level. The thickness of terrace sediments in the whole segment is quite constant, i.e. about $5 \mathrm{~m}$. Terrace localities are preserved almost exclusively in the convex position of valley meanders and bends.

\section{Terrace V (Městečko)}

The Sázava terrace V (Městečko) follows the flow of the river in the regular level gradient reach between both gradient steps, i.e. between Ledeč nad Sázavou and Týnec 
nad Sázavou (river kilometres 127-20). The highest position of the Městečko Terrace is in a valley bend about $2 \mathrm{~km} \mathrm{WNW}$ of Ledeč nad Sázavou. Its surface was determined by borings at $351 \mathrm{~m}$ and its base at $347 \mathrm{~m}$, i.e. $7 \mathrm{~m}$ and $3 \mathrm{~m}$ above the river (Dittrichová 1989). In a meander E of Budčice and NNE of Kounice, 3 to $5 \mathrm{~m}$ thick gravelly sands were found with their surface at about 4-5 m above the floodplain on the terrace V level (Adler 1977). A more extensive occurrence of sediments of terrace $\mathrm{V}$ follows the right bank of the Sázava between Březina and the Horka nad Sázavou railway station (between river kilometres 109 and 112, Fig. 2). Terrace V is preserved here in the neighbourhood of terrace III. Deposits eroded to the level of the bottom of an abandoned sandpit near the railway Horka nad Sázavou station consist of light grey cross-stratified and loose sands to fine gravels. Their surface at $336 \mathrm{~m}$ is situated $9 \mathrm{~m}$ above the undammed Sázava level and the base of the deposits was found at 334-327 m, i.e. the lowest position is that of the river level (Rybařík 1968).

In a deeply incised meander valley between the mouth of the Blanice and the town of Sázava, terrace $\mathrm{V}$ is only exceptionally preserved in the convex parts of valley bends and meanders. A pronounced plateau is, however, formed by terrace $\mathrm{V}$ in the valley meander in the town of Sázava in the $\mathrm{N}$ neighbourhood of the railway line (between river kilometres 57 and 54). The plateau is slightly inclined towards the river: from $293-291 \mathrm{~m}$ (9-7 $\mathrm{m}$ of relative height) to $289-287 \mathrm{~m}$, where it passes into the surface of terrace VI (Fig. 4). Several borings proved mostly 3.0 to $5.5 \mathrm{~m}$ (sporadically up to $8.5 \mathrm{~m}$ ) thick sands with gravel and sandy gravels (with quartz and crystalline rocks pebbles and cobbles of 3 to $10 \mathrm{~cm}$ in diameter, revealing a maximum of $30 \mathrm{~cm}$ ). Their base mostly occurs at 287-289 $\mathrm{m}$ and the lowest at 282-283 m (Luštincová 1969, Čechová 1969, Dvořák 1971). The lowest position of the base probably developed in a shallow deepened furrow. The terrace sediments are locally covered by up to $2.5 \mathrm{~m}$ thick sandy loam. The rock substrate beneath the terrace deposits is formed by weathered Moldanubic mica schist to paragneiss.

The surface of terrace V in a Sázava bend near Městečko, between river kilometres 31.5 and 29.0, is covered by frequent well-rounded gravels of up to $15 \mathrm{~cm}$ in diameter, revealing a maximum of $20-50 \mathrm{~cm}$, and situated at 274-277.5 $\mathrm{m}$ (11-13.5 $\mathrm{m}$ above the Sázava level). The higher level of its granodiorite base is at $274.5-275.7 \mathrm{~m}$ (the thickness of sands with gravels is $2-3 \mathrm{~m}$ ), and the lower level of the base is at 269.0-270.6 $\mathrm{m}$ (the thickness of sands with gravels is 4-5 m, Passer 1967a). This plateau is separated to the $\mathrm{S}$ from the surface of terrace VI by an indistinct step, about $5 \mathrm{~m}$ high.

Terrace V (Městečko), preserved in a long segment of the middle course between both level gradient steps, is seen downstream in a slight divergence with the Sázava level: surface from 7-9 $\mathrm{m}$ to $11-13 \mathrm{~m}$ and base from $2-3 \mathrm{~m}$ to $5-7 \mathrm{~m}$. In the larger fragment near Zruč nad Sázavou, the base of terrace V is often identical with the position of the rock underlayer of sediments of terrace III, and also in segments outside the abandoned valleys of the Chabeřice Terrace. It can thus be presumed that, during the erosional stage before the accumulation of sediments of the Městečko Terrace (V), the erosion of the stream after the end of the accumulation of the Týnec Terrace (IV) reached only the level of the base of terrace III. Gravelly sands, rarely sandy gravels, are mostly about $5 \mathrm{~m}$ thick and, with the exception of the town of Sázava (thickness 
of $10.2 \mathrm{~m}$ ) where not over $8 \mathrm{~m}$ thickness of sediments was found by borings. The Sázava terrace V corresponds to the Vltava group of terraces IIIa and IIIb (ZárubaPfeffermann 1943), or to the Dejvice Terrace V (Záruba et al. 1977).

\section{Terrace VI (Poříči)}

The Sázava terrace VI (Poříčí) is preserved at several localities of mostly limited extent (Photo 6) in an about $110 \mathrm{~km}$ long segment of the river's middle course with normal gradient. The furthest position upstream that this terrace was found was in the convex part of a valley bend in Ledeč nad Sázavou - Podol (river kilometre 128). Here there 4-5 m thick sands with gravels with their surface at 351-352 m, i.e. about $2 \mathrm{~m}$ above the floodplain were found in borings (Marek 1980). In a meander W of Vlastějovice, between river kilometres 113 and 112 (Fig. 2), aggradations of terrace VI border the floodplain in a relative height of about $4 \mathrm{~m}$. This locality is related to an occurrence on the right bank downstream of Březina, where a small narrow plateau overlain by gravels is situated 2-3 $\mathrm{m}$ above the floodplain surface.

The principal localities verified by borings are preserved in larger areas in the town of Sázava, in Sázava - Černé Budy and in small valley basins in the neighbourhood of Čerčany, Poříčí nad Sázavou and Týnec nad Sázavou (Photo 6). The terrace VI surface in the direction downstream diverges slightly from the present level, from 3-4 $\mathrm{m}$ to 6-8 $\mathrm{m}$. The sandy gravels and gravelly sands of this terrace are about $5 \mathrm{~m}$ thick, reaching a maximum of 7-8 $\mathrm{m}$ thick. The base of the terrace is situated approximately at the level of the river or of the floodplain, i.e. on a level of the lowest position of the base of terrace III upstream from Zruč nad Sázavou. This implies that during the erosional stage between accumulations of terrace V and terrace VI the Sázava valley was only deepened here to the presumed level of the terrace III base. Occurrences of the Poříći Terrace are often covered by deluvial deposits (Fig. 5), by material of alluvial cones of streams and also in lower parts by Holocene flood sediments. In the Vltava terrace system the Sázava terrace VI probably corresponds to the Veltrusy Terrace, classified as Riss 2, or Warthe by Záruba-Pfeffermann (1943) and Záruba et al. (1977).

\section{Terrace VII (Pikovice)}

The only distinctive locality of the higher level of the Sázava terrace VII occurs in the $\mathrm{N}$ part of Pikovice, where its surface is at $210 \mathrm{~m}$, i.e. $10 \mathrm{~m}$ above the undammed river level. Terrace sediments here are covered by deposits of an alluvial cone at the mouth of erosional furrows and short valleys (Figs 4 and 5). In the Vltava terrace system, the Pikovice Terrace is related to the Maniny Terrace (VII), which according to the longitudinal profile by Q. Záruba (Záruba-Pfeffermann 1943), has its surface at about $215 \mathrm{~m}$ here (19 $\mathrm{m}$ above the original - before dammed - level). This is about 5-6 m higher than the presumed highest surface of the Pikovice Terrace. In his later work, this author classifies the valley level as terrace VII stratigraphically corresponding to the Würmian Stage (Záruba et al. 1977).

An accumulation plateau in the $\mathrm{N}$ neighbourhood of the Pikovice Terrace with its higher surface at 204-205 m corresponds to the lower level of terrace VII and its lower 
surface near the river at 202-203 m already belongs to the floodplain. The terrace step VII, with its surface 4-5 $\mathrm{m}$ above the undammed Sázava level, has its base of 5-7 m thick coarse to bouldery gravels, on Proterozoic slates at $197 \mathrm{~m}$. Sediments of terrace VII in the middle Sázava course probably form the gravelly sand and gravel infilling of the present valley floor under the Holocene floodplain sediments.

\section{Floodplain}

The modern floodplain of the Sázava river is developed as the youngest level of the terrace system continuously along the valley. Both segments of the increased level gradient in the Melechov massif (river kilometres 140-135) and on the lowest course downstream from Týnec nad Sázavou (river kilometres 17-5) are exceptional, and here the floodplain is only intermittently. The floodplain surface, formed mostly on 1-3 m thick Holocene flood sediments (loams, sands, clays), is situated about 1-2 m above the undammed river level. The floodplain locally has two levels - the lower at about $1 \mathrm{~m}$ above the river and the higher, occasionally up to 2.5-3 $\mathrm{m}$ above the river. The latter is often accentuated by slope wash sediments or flat alluvial-cone deposits. The underlying sandy gravels of Pleistocene age (Weichselian or Eemian) are mostly 3-6 m thick. The valley-bottom long profile shows a slight increase in the thickness of the floodplain sediments between river kilometres 80 and 32, and their reduction mainly at the beginning of the increased gradient of the lower course.

The dimensions of the floodplain correspond to the prevailing erosional character of the Sázava valley. It is generally developed to a width of only several tens of metres (mostly 100 to $150 \mathrm{~m}$ ). The floodplain is wider at mouths of larger tributaries, in some valley meanders and bends or in small valley basins: near Havlíčkův Brod 200-400 m, near Světlá nad Sázavou up to $250 \mathrm{~m}$, near Kácov at the mouthing of the Losinský potok Brook 150-250 m (Fig. 3), near the town of Sázava and at the mouthing of the Vlkančický potok Brook 150-250 m, near Poříčí nad Sázavou (Fig. 5) and near Pikovice up to $200 \mathrm{~m}$. The floodplain in the Sázava valley nowhere exceeds $500 \mathrm{~m}$ wide.

\section{Conclusions}

Regarding the distribution and area expansion of the seven terrace steps of the Sázava river, the following results are worthy of note:

1. The oldest, mostly higher Middle Pleistocene terraces are only preserved sporadically in limited occurrences (Photos 2, 3 and 4), and they occur above the margin of the incised valley. Accumulation terrace covers are mostly thin, as a rule they do not exceed $5 \mathrm{~m}$, and at many localities but at mainly those at higher levels, they are denudation relics of initially thicker terrace sediments. Here they comprise plateaux with gravels mostly of minor thickness (1-2 m), which eventually became only dispersed cobbles, often only partially rounded. The thick accumulations of terrace III in the middle course near Zruč nad Sázavou are exceptional.

2. The degree of rounding of the gravel clasts is mostly minor to middle. Therefore, especially at higher levels, the subangular gravels are significantly predominate over 
the more perfectly rounded clasts. There are also, mainly in abandoned segments, frequent sharp-edged fragments and boulders, eventually slightly rounded gravels with traces of aeolian corrasion in thicker terrace accumulations.

3. Fluvial accumulations of unusual thickness occur in the middle course of the Sázava (in the area around Zruč nad Sázavou, Photo 4). They mostly represent fillings of abandoned valley segments preserved because of the relocation of the bed to the present valley. Correlation of Sázava river terraces with the Vltava-Labe terrace systems and their chronostratigraphical positions are performed in Table 1.

4. Contrary to other Czech rivers, the terrace localities of the Sázava river are mostly not represented geomorphologically and only rarely occur in marked topographic steps. Practically nowhere do terraces follow the Sázava river in direct segments (lateral terraces), they are often developed on the convex parts of bends and meanders (meander terraces). In the lateral form, higher terrace levels occur mainly in the Sázava lowest course.

\section{Acknowledgement}

This paper was elaborated within the research project of the Faculty of Science, Charles University in Prague, MSM 0021620831 "Geographical systems and risk processes in the context of global changes and European integration".

\section{References}

ADLER, J. (1977): Zpráva o inženýrskogeologickém průzkumu základové půdy v prostoru letního tábora „Praga“v Kounicích. Projekta Praha, MS Geofond V 78 312, Praha.

BALATKA, B. (2007): River terraces and the Sázava Valley evolution. In: Goudie, A. S. and Kalvoda, J. (eds.): Geomorphological Variations. Nakladatelství P3K, Prague, pp. 361-386.

BALATKA, B., KALVODA, J. (2006): Geomorfologické členění reliéfu Čech. Geomorphological regionalization of the relief of Bohemia. Kartografie, a. s., Praha, 79 p., 3 maps.

BALATKA, B., KALVODA, J. (2008): Evolution of Quaternary river terraces related to the uplift of the central part of the Bohemian Massif. Geografie - Sborník České geografické společnosti, 113, 3, Praha, pp. 205-222.

BALATKA, J., KALVODA, J. (2010): Vývoj údolí Sázavy v mladším kenozoiku. Nakladatelství České geografické společnosti, Praha, 198 p.

BALATKA, B., LOUČKOVÁ, J. (1992): Terasový systém a vývoj údolí Berounky. Studia geographica, 96, Geografický ústav ČSAV, Brno, 53 p.

BALATKA, B., LOUČKOVÁ, J., SLÁDEK, J. (1966): Vývoj hlavní erozní báze českých řek. Rozpravy ČSAV, ř. MPV, r. 76, seš. 9, Academia, Praha, 76 p.

BALATKA, B., SLÁDEK, J. (1962): Říční terasy v českých zemích. Geofond v NČSAV, Praha, 580 p.

BALATKA, B., SLÁDEK, J. (1977): Evorzní tvary v Čechách a jejich geneze. Rozpravy ČSAV, ř. MPV, r. 87, seš. 7, Academia, Praha, 98 p.

BALATKA, B., ŠTĚPANČÍKOVÁ, P. (2006): Terrace system of the midle and lower Sázava River. Geomorphologia Slovaca, 6, 1, 7 figs., Bratislava, pp. 69-81.

BUDAY, T., KODYM , O. ST., MAHEL, M., MÁŠKA, M., MATĚJKA, A., SVOBODA, J., ZOUBEK, V. (1961): Tektonický vývoj Československa (s tektonickou mapou 1 : 1000 000). ÚÚG v NČSAV, Praha, $254 \mathrm{p}$.

CZUDEK, T. ed. et al. (1972): Geomorfologické členění ČSR. Studia geographica 23, Geografický ústav ČSAV, Brno, 137 p. 
ČECHOVÁ, E. (1969): Závěrečná zpráva, Sázava nad Sázavou. Stavební geologie Praha, MS Geofond V 61 734, Praha.

ČIHÁK, P., ŠILHAN, L. (1988): Zpráva o geologickém průzkumu Kácov - výstavba kanalizace, ČOV, vodovodu a vodojemu. Státní ústav dopravního projektování (SVDOP) Pardubice, MS Geofond P 63 793, Praha.

DANEŠ, J. V. (1913): Morfologický vývoj středních Čech. Sborník České společnosti zeměvědné, 19, Praha, pp. 1-18, 94-108, 168-176.

DEMEK, J. ed. et al. (1987): Zeměpisný lexikon ČSR. Hory a nížiny. Academia, Praha, 584 p.

DEMEK, J., MACKOVČIN, P. eds. et al. (2006): Zeměpisný lexikon ČR: Hory a ní̌iny. Vydání II. Agentura ochrany prírody a krajiny ČR, Praha, $582 \mathrm{p}$.

DITTRICHOVÁ, Š. (1989): Závěrečná zpráva IG průzkumu Ledeč nad Sázavou - ČOV. Geoindustria Praha, MS Geofond P 72 614, Praha.

DVOǨÁK, P. (1971): Závěrečná zpráva o inženýrskogeologickém průzkumu na staveništi bytových jednotek v Sázavě n. Sáz. Stavební geologie Praha, Sázava nad Sázavou, MS Geofond V 65 411, Praha.

ENGELMANN, R. (1938): Der Elbedurchbruch. Geomorphologische Untersuchungen im oberen Elbgebiete. Abhandlungen der Geographischen Gesellschaft in Wien, 13, 2, Wien, 139 p.

GIBBARD, P. L., BOREHAM, S., COHEN, K. M., MOSCARIELLO, A. (2004): Global chronostratigraphical cerrelation table for the last 2.7 million years. Quaternary Palaeoenvironment Group, University of Cambridge, Cambridge, 2 p., 1 tab.

GIBBARD, P. L., HEAD, M. J., WALKER, M. J. C. and the Subcomission on Quaternary Stratigraphy (2009): Formal ratification of the Quaternary System/Period and the Pleistocene Series/Epoch with a base at $2.58 \mathrm{Ma}$. Journal of Quaternary Science. (www.interscience.wiley.com) DOI: 10.1002/jqs.1338

GEOLOGICAL MAP OF THE CZECH REPUBLIC 1: 500000 (2007). Česká geologická služba, Praha.

HAŠLAR, O. (1959): Průzkum štěrkopísků 1959 Kácov. Geologický průzkum n. p. Praha, závod Buchlovice, Tuchlovice, MS Geofond FZ 3036, Praha.

HRUBEŠ, M. (1995): Terciérní a kvartérní sedimenty na listu 23-21 Havlíčkův Brod. Zprávy o geologických výzkumech v roce 1994, Praha, pp. 62-63.

HUGHES, P. D. (2007): Allostratigraphy/Morphostratigraphy. In: Elis, S. (ed.): Quaternary Stratigraphy. Encyclopedia of Quaternary Sciences. Elsevier, Amsterdam, pp. 2841-2846.

HUŠNER, V. (1970): Závěrečná zpráva o doplňujícím inženýrsko-geologickém průzkumu ložiska písků ve Zruči nad Sázavou (Domahoři). Stavební geologie Praha, MS Geofond P 22 099, Praha.

KALVODA, J. (2007): Morphostructural evolution of the relief in the locality of the Geodynamic Observatory at Pecný, the Ondřejovská vrchovina Highland, Czech Republic. In: Goudie, A. S., Kalvoda, J. (eds): Geomorphological Variations. P3K Publishers, Prague, pp. 387-407.

KALVODA, J., BALATKA, B. (2006): Morfostrukturní vývoj reliéfu české části Českého masivu. Morphostructural evolution of the relief of the Bohemian part of the Český Masiv Massif. In: Balatka, B., Kalvoda, J.: Geomorfologické členění reliéfu Čech. Kartografie, a. s., Praha, pp. 5-12.

KLEČEK, M., KRÁL, J., LOCHMANN, Z. (2001): Inženýrskogeologické poměry. In: Kovanda, J. a spolupracovníci: Neživá příroda Prahy a jejího okolí. Academia, Český geologický ústav, Praha, 216 p. (kap. 14, pp. 133-148).

KLOMíNSKÝ, J. ed. et al. (1994): Geologický atlas České republiky. Stratigrafie. Český geologický ústav, Praha, 17 listů.

KODYM, O. RED., DOMAS, J., HOLUB, V., MAŠEK, J. (1993): Geologická mapa ČR. List 13-31 Říčany. Český geologický ústav, Praha.

KRÁL, J. (1969): Dálnice $D_{1}$ Praha-Brno, úsek Soutice-Píšt, pískovny: Zruč n. S., Buda. Vojenský projektový ústav, MS Geofond P 21 793, Praha.

KRÁL, J. (1971): Zpráva o ložiskovém průzkumu štěrkopísků Kožlí. Vojenský projektový ústav Praha, MS Geofond P 22 588, FZ 5 172, Praha.

KRÁL, J. (1973): Závěrečná zpráva Bojiště - U - 2701/30, surovina: štěrkopísek. Vojenský projektový ústav Praha, MS Geofond, FZ 5 170, Praha.

KREJČÍ, J. (1939): Profil rovnováhy jakožto základ studia říčních teras. Spisy Odboru české společnosti zeměpisné v Brně, řada $\mathrm{A}$, č. 5, Brno, $144 \mathrm{p}$.

KŮTA, L. (1956): Průzkum štěrkopísků v ČSR - 1956, Chabeřice. Nerudný průzkum, n. p. v Brně, MS Geofond FZ 2 314, Praha. 
LOŽEK, V., ŽÁK, K., CÍLEK, V. (2004): Z minulosti českých řek. Vesmír 83, Praha, pp. 447-453.

LUŠTINCOVÁ, L. (1969): Zpráva o výsledku inženýrskogeologického průzkumu pro výstavbu sídliště v Sázavě n. Sáz. Stavební geologie Praha, MS Geofond V 60 590, Praha.

MALKOVSKÝ, M. (1975): Paleogeography of the Miocene of the Bohemian Massif. Věstník Ústředního ústavu geologického, 50, 1, Praha, pp. 27-31.

MALKOVSKÝ, M. (1976): Saxonische Tektonik der Böhmische Masse. Geologische Rundschau, 65, Stuttgart, pp. 127-143.

MALKOVSKÝ, M. (1979): Tektogeneze platformního pokryvu Českého masívu. ÚÚG v Academii, Praha, $176 \mathrm{p}$.

MAREK, V. (1980): Závěrečná zpráva o inženýrskogeologickém průzkumu projektovaných staveništ n. p. Kovofiniš Ledeč nad Sázavou. Stavební geologie Praha, Ledeč nad Sázavou, MS Geofond P 29 477, Praha.

MAŠEK, J. red. et al. (1984): Vysvětlivky k základní geologické mapě ČSSR 1 . 25 000, 12-423 Davle. Ústřední ústav geologický, Praha, $67 \mathrm{p}$.

MÍSǍ̌, Z., DUDEK, A., HAVLENA, V., WEISS, J. (1983): Geologie ČSSR I. Český masív. Státní pedagogické nakladatelství, Praha, $336 \mathrm{p}$.

MOSCHELESOVÁ, J. (1930): Vlnité prohyby o velké amplitudě v jižních Čechách. Sborník Československé společnosti zeměpisné, 36, Praha, pp. 155-158.

MÜLLER, V. ed. et al. (1993): Vysvětlivky k souboru geologických a ekologických účelových map př́rodních zdrojů v měřítku 1: 50 000. List 13-31 Říčany. Český geologický ústav Praha, Praha, 32 p.

MÜLLER, V. ed., JINOCHOVÁ, J., KADLEC, J. et al. (2002): Vysvětlivky k souboru geologických a ekologických účelových map př́rodních zdrojů v měřítku 1: 50 000. List 13-33 Benešov. Česká geologická služba, Praha, $40 \mathrm{p}$.

NOVÁK, V. J. (1930): Příspěvky ku poznání vývoje dolní Sázavy. Sborník Československé společnosti zeměpisné, 36, Praha, pp. 150-155.

NOVÁK, V. J. (1932): Vývoj úvodí a údolí řeky Sázavy. Věstník Královské České společnosti nauk, 11, Praha, $47 \mathrm{p}$.

NOVÁK, V. J. (1943): Tvářnost Českomoravské vysočiny. Rozpravy II. třídy České akademie, r. 52, č. 20, Praha, $101 \mathrm{p}$.

PASSER, M. (1967a): Závěrečná zpráva Praha-Mirošovice-Benešov. Suroviny pro stabilizaci cementem. Závěrečná zpráva pro výpočet zásob surovin pro stabilizaci cementem. Stav ke dni: 31. 12. 1966. Geologický průzkum, n. p. Praha, MS Geofond P 18 884, Praha.

PASSER, M. (1967b): Závěrečná zpráva Mirošovice-Soutice-Měřín. Surovina: cementové stabilizace. Geologický průzkum, n. p., Praha, MS Geofond P 20 266, Praha.

PILECKÁ, M. (1997): Údolní meandry, jejich geneze a morfometrické charakteristiky. Bakalářská práce, PřF UK, Praha, $35 \mathrm{p}$.

PROCHÁZKA, J., MLČOCH, B. (1998): Komplexní geologický výzkum melechovského masivu. Zprávy o geologických výzkumech v roce 1997, Praha, pp. 31-37.

PUFFER, L. (1930): Die Sazauterrassen um Pikovice - Petrov. XXXI. Jahresbericht der deutschen Staatsrealschule in Prag, pp. 6-8.

RYBÁŘ, J. (1958): Závěrečná zpráva o geologickém průzkumu ve Zruči nad Sázavou. Geologický průzkum, n. p., Ústav stavební geologie, MS Geofond P 12 231, Praha.

RYBAŘíK, V. (1968): Závěrečná zpráva úkolu Mirošovice-Soutice-Měřín. Úsek Soutice-Píšt. Surovina: zeminy, etapa vyhledávací. Geoindustria, n. p., Praha, Jihlava, MS Geofond P 21 463, Praha.

SMETANA J. (1933): Podélné a př́čné profily československých řek. Sešit 7. Podélný profil Sázavy v měřítku $1: 10000$ pro délky a $1: 200$ pro výšky s význačnými př̌́čnými profily v měřítku $1: 400$ pro délky a $1: 200$ pro výšky od Německého Brodu k ústí (km 162,940-0,000). - Státní výzkumný ústav hydrologický T. G. Masaryka v Praze, 49 p., Praha.

S̆IBRAVA, V. (1972): Zur Stellung der Tschechoslowakei im Korrelierungssystem des Pleistozäns in Europa. Sborník geologických věd, Antropozoikum, ř. A, sv. 8, pp. 5-218.

ŠTĚPANČíKOVÁ, P. (2003): Terasy dolní Sázavy v úseku od Vrabčího Brodu po Kamenný Přívoz. Geografie - Sborník České geografické společnosti, r. 108, č. 3, Praha, pp. 216-226.

ŠTĚRBA, J. (1976): Závěrečná zpráva inženýrskogeologického průzkumu pro PÚP Zruč nad Sázavou. Geoindustria, MS Geofond P 25 110, Praha. 
TYRÁČEK, J. (2001): Upper Cenozoic fluvial history in the Bohemian Massif. Quaternary International, 79, pp. 37-53.

TYRÁČEK, J., WESTAWAY, R., BRIDGLAND, D. (2004): River terraces of the Vltava and Labe (Elbe) system, Czech Republic, and their implications for the uplift history of the Bohemian Massif. Proceedings of the Geologists' Association, 115, pp. 101-124.

TYRÁČEK, J., HAVLÍČEK P. (2009): The fluvial record in the Czech Republic. A review in the context of IGCP 518. Global and Planetary Change, doi:10.1016/j.gloplacha.2009.03.007

VÁCLAVEK, V. (1970): Výpočet zásob ložiska Domahoř. Surovina: těžené kamenivo drobné, štěrkopísek a písek. MNV Zruč nad Sázavou, MS Geofond FZ 5 077, Praha.

ZÁRUBA-PFEFFERMANN, Q. (1941): Původ štěrků z terasy u Lysolej a Suchdola. Zprávy Geologického ústavu pro Čechy a Moravu, 17, Praha, pp. 298-308.

ZÁRUBA-PFEFFERMANN, Q. (1943): Podélný profil vltavskými terasami mezi Kamýkem a Veltrusy. Rozpravy II. tř. České akademie, r. 52, č. 9, Praha, 39 p.

ZÁRUBA, Q., BUCHA, V., LOŽEK, V. (1977): Significance of the Vltava terrace system for Quaternary chronostratigraphy. Rozpravy ČSAV, ř. MPV, r. 87, seš. 4, Academia, Praha, 90 p.

ZÁRUBA, Q., RYBÁ̌̆, J. (1961): Doklady pleistocenní agradace údolí Sázavy. Sborník Československé společnosti zeměpisné, 66, Praha, pp. 23-30.

Table 1 Correlation of Sázava River terraces with the Vltava-Labe terrace systems and their chronostratigraphical position

\begin{tabular}{|c|c|c|c|c|}
\hline $\begin{array}{c}\text { Regional } \\
\text { stratigraphical } \\
\text { division of the } \\
\text { Quaternary } \\
\text { (Gibbard et al. } \\
\text { 2004, 2009) }\end{array}$ & $\begin{array}{c}\text { SÁZAVA } \\
\text { Balatka, } \\
\text { Kalvoda } \\
(\mathbf{2 0 0 8 , 2 0 1 0 )})\end{array}$ & $\begin{array}{c}\text { Confluence area } \\
\text { of VLTAVA } \\
\text { and LABE } \\
\text { Balatka, } \\
\text { Sládek (1962), } \\
\text { Šibrava (1972) }\end{array}$ & $\begin{array}{c}\text { VLTAVA } \\
\text { Záruba et al. } \\
\text { (1977) }\end{array}$ & $\begin{array}{c}\text { Complex } \\
\text { of VLTAVA } \\
\text { and LABE } \\
\text { Tyráček (2001), } \\
\text { Tyráček et al. } \\
\text { (2004), Tyráček, } \\
\text { Havlíček (2009) }\end{array}$ \\
\hline $\begin{array}{l}\text { Late Pleistocene } \\
\text { Weichselian }\end{array}$ & $\begin{array}{l}\text { Pikovice } \\
\text { Terrace } \\
\text { (VII) }\end{array}$ & $\begin{array}{c}\text { Hostín } \\
\text { Terrace } \\
(\text { VIIa, b, c, d) }\end{array}$ & $\begin{array}{l}\text { Maniny } \\
\text { Terrace } \\
\text { (VII) }\end{array}$ & $\begin{array}{l}\text { Maniny Terrace } \\
\text { (Weichselian) } \\
\text { Hostín } 1 \text { Terrace }\end{array}$ \\
\hline $\begin{array}{l}\text { Middle Pleistocene } \\
\text { Saalian (Warthe) }\end{array}$ & $\begin{array}{l}\text { Poříčí } \\
\text { Terrace } \\
\text { (VI) }\end{array}$ & $\begin{array}{l}\text { Mlčechvosty } \\
\text { Terrace } \\
\text { (VIa, b, c) }\end{array}$ & $\begin{array}{l}\text { Veltrusy } \\
\text { Terrace } \\
\text { (VI) }\end{array}$ & $\begin{array}{l}\text { Veltrusy } \\
\text { Terrace } \\
\text { (Warthe) }\end{array}$ \\
\hline $\begin{array}{c}\text { Middle Pleistocene } \\
\text { Saalian } \\
\text { (Drenthe) }\end{array}$ & $\begin{array}{l}\text { Městečko } \\
\text { Terrace } \\
\text { (V) }\end{array}$ & $\begin{array}{c}\text { Cítov } \\
\text { Terrace } \\
(\mathrm{Va}, \mathrm{Vb})\end{array}$ & $\begin{array}{l}\text { Dejvice } \\
\text { Terrace } \\
\text { (V) }\end{array}$ & $\begin{array}{c}\text { Dejvice } 1 \text { and } 2 \\
\text { Terrace } \\
\text { (Drenthe) }\end{array}$ \\
\hline $\begin{array}{l}\text { Middle Pleistocene } \\
\text { Saalian (Fuhne) }\end{array}$ & $\begin{array}{l}\text { Týnec } \\
\text { Terrace } \\
\text { (IV) }\end{array}$ & $\begin{array}{l}\text { Hněvice Hill } \\
\text { Terrace } \\
\text { (IV) }\end{array}$ & $\begin{array}{l}\text { Letná } \\
\text { Terrace } \\
\text { (IV) }\end{array}$ & $\begin{array}{l}\text { Letná Terrace } \\
\text { (Fuhne) }\end{array}$ \\
\hline $\begin{array}{l}\text { Middle Pleistocene } \\
\text { Elsterian }\end{array}$ & $\begin{array}{c}\text { Buda Terrace } \\
\text { (IIIb) }\end{array}$ & (IIIb) & $\begin{array}{l}\text { Vinohrady } \\
\text { Terrace } \\
\text { (IIIB) }\end{array}$ & $\begin{array}{l}\text { Vinohrady } \\
\text { Terrace } \\
\text { (Elsterian) }\end{array}$ \\
\hline $\begin{array}{c}\text { Middle Pleistocene } \\
\text { Cromerian Complex } \\
\text { (Glacial c) }\end{array}$ & $\begin{array}{l}\text { Chabeřice } \\
\text { Terrace } \\
\text { (IIIa) }\end{array}$ & $\begin{array}{l}\text { Straškov } \\
\text { Terrace } \\
\text { (IIIa) }\end{array}$ & $\begin{array}{l}\text { Kralupy } \\
\text { Terrace } \\
\text { (IIIA) }\end{array}$ & $\begin{array}{c}\text { Kralupy } \\
\text { Terrace } \\
\text { (Cromerian C) }\end{array}$ \\
\hline
\end{tabular}




\begin{tabular}{|c|c|c|c|c|}
\hline $\begin{array}{c}\text { Regional } \\
\text { stratigraphical } \\
\text { division of the } \\
\text { Quaternary } \\
\text { (Gibbard et al. } \\
\text { 2004, 2009) }\end{array}$ & $\begin{array}{c}\text { SÁZAVA } \\
\text { Balatka, } \\
\text { Kalvoda } \\
(\mathbf{2 0 0 8 , 2 0 1 0 )}\end{array}$ & $\begin{array}{c}\text { Confluence area } \\
\text { of VLTAVA } \\
\text { and LABE } \\
\text { Balatka, } \\
\text { Sládek (1962), } \\
\text { Śibrava (1972) }\end{array}$ & $\begin{array}{c}\text { VLTAVA } \\
\text { Záruba et al. } \\
(1977)\end{array}$ & $\begin{array}{c}\begin{array}{c}\text { Complex } \\
\text { of VLTAVA }\end{array} \\
\text { and LABE } \\
\text { Tyráček (2001), } \\
\text { Tyráček et al. } \\
\text { (2004), Tyráček, } \\
\text { Havlíček (2009) }\end{array}$ \\
\hline $\begin{array}{c}\text { Middle Pleistocene } \\
\text { Cromerian Complex } \\
\text { (Glacial c) }\end{array}$ & $\begin{array}{l}\text { Český Šternberk } \\
\text { Terrace } \\
\text { (II) }\end{array}$ & $\begin{array}{l}\text { Ledčice } \\
\text { Terrace } \\
\text { (II) }\end{array}$ & $\begin{array}{l}\text { Pankrác } \\
\text { Terrace } \\
\text { (II) }\end{array}$ & $\begin{array}{c}\text { Pankrác } \\
\text { Terrace } \\
\text { (Cromerian C) }\end{array}$ \\
\hline $\begin{array}{c}\text { Middle Pleistocene } \\
\text { Cromerian Complex } \\
\text { (Glacial b) }\end{array}$ & $\begin{array}{l}\text { Hvězdonice } \\
\text { Terrace } \\
\text { (Ib) }\end{array}$ & & $\begin{array}{l}\text { Suchdol } \\
\text { Terrace } \\
\text { (IB) }\end{array}$ & $\begin{array}{c}\text { Suchdol } \\
\text { Terrace } \\
\text { (Cromerian B) }\end{array}$ \\
\hline $\begin{array}{c}\text { Middle Pleistocene } \\
\text { Cromerian Complex } \\
\text { (Glacial a) }\end{array}$ & $\begin{array}{l}\text { Střechov } \\
\text { Terrace } \\
\text { (Ia) }\end{array}$ & $\begin{array}{l}\text { Krabčice } \\
\text { Terrace } \\
\text { (I) }\end{array}$ & $\begin{array}{l}\text { Lysolaje } \\
\text { Terrace } \\
\text { (IA) }\end{array}$ & $\begin{array}{c}\text { Lysolaje } \\
\text { Terrace } \\
\text { (Cromerian A) }\end{array}$ \\
\hline $\begin{array}{c}\text { Early Pleistocene } \\
\text { Bavelian (Dorst) } \\
\text { Menapian }\end{array}$ & & $\begin{array}{l}\text { Rovné } \\
\text { Terrace }\end{array}$ & & $\begin{array}{l}\text { Rovné Terrace } \\
\text { (Dorst) } \\
\text { Vráž Terrace } \\
\text { (Menapian) }\end{array}$ \\
\hline $\begin{array}{l}\text { Early Pleistocene } \\
\text { Eburonian, } \\
\text { Menapian }\end{array}$ & $\begin{array}{l}\text { Niveau B } \\
\text { Radvanice }\end{array}$ & $\begin{array}{l}\text { Stříbrníky } \\
\text { Terrace }\end{array}$ & $\begin{array}{c}\text { Zdiby } \\
\text { Stadium } \\
\text { (Pliocene) }\end{array}$ & $\begin{array}{c}\text { Zdiby Terrace } \\
\text { (Eburonian- } \\
\text { Menapian) }\end{array}$ \\
\hline $\begin{array}{c}\text { Early Pleistocene } \\
\text { Tiglian }\end{array}$ & & & & $\begin{array}{l}\text { Stř́ibrníky Terrace } \\
\text { (upper Tiglian) }\end{array}$ \\
\hline $\begin{array}{l}\text { Neogene } \\
\text { (Miocene) }\end{array}$ & $\begin{array}{c}\text { Niveau A } \\
\text { Boiiiště }\end{array}$ & & $\begin{array}{l}\text { Klínec } \\
\text { Stadium }\end{array}$ & $\begin{array}{l}\text { Kobylisy } \\
\text { Sands }\end{array}$ \\
\hline
\end{tabular}




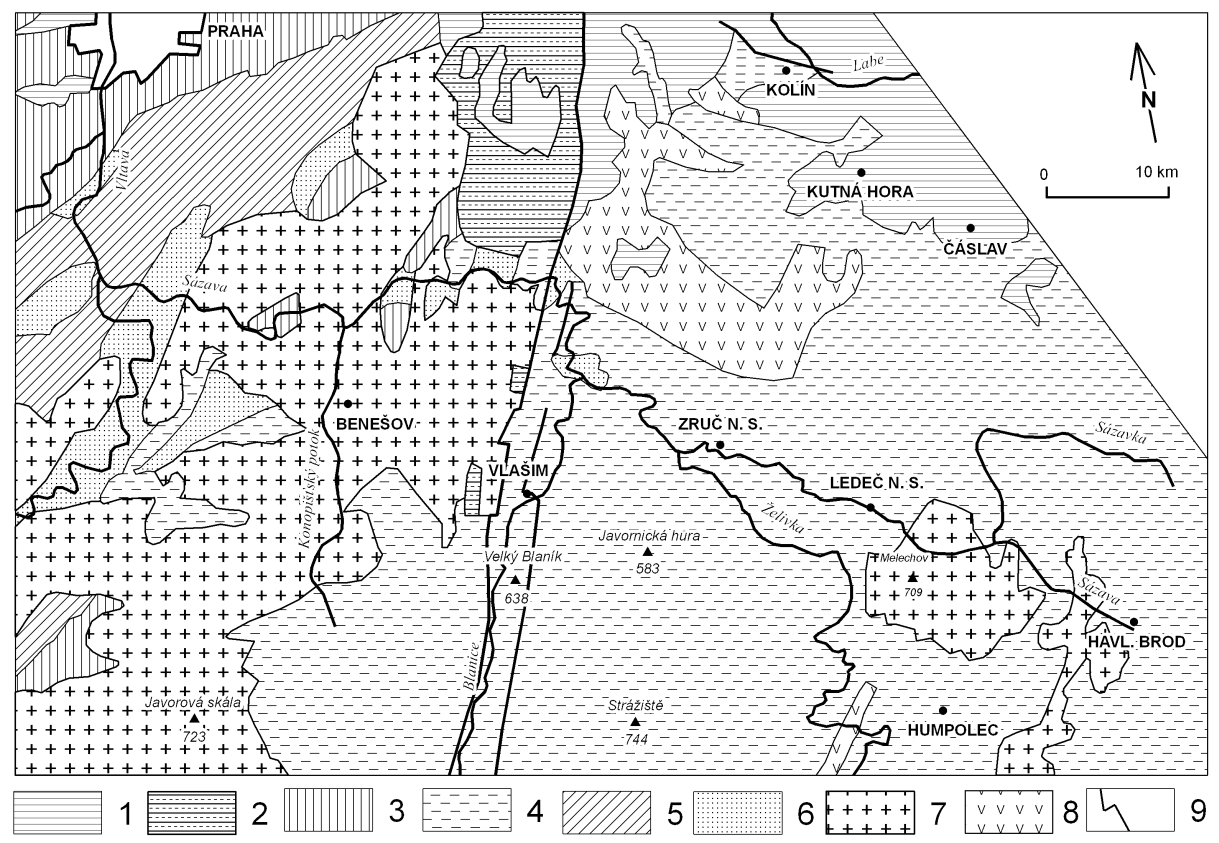

Fig. 1 Geological sketch of the Sázava catchment and neighbouring areas (modified after Klomínský et al. 1994, Geological map of the Czech Republic 2007): Key: 1 - Upper Cretaceous (Cenomanian, Turonian): claystones, siltstones and conglomerates; 2 - Permian and Carbonian (autun, stephan): mudstones, sandstones, arcoses and conglomerates; 3 - Lower Palaeozoic (Devonian, Silurian, Ordovician, Cambrian): sandstones, conglomerates, slates, siltstones, limestones, quartzites and basalts; 4 - Pre-Cambrian and (or) Palaeozoic (undistinguished): phyllites, mica shists, gneisses, migmatized gneisses, migmatites, quartzites and erlans; 5 - Neo-Proterozoic: slates, graywackes and vulcanites, 6 - Pre-Cambrian and Palaeozoic vulcanites and meta vulcanites: rhyolites, dacites, tuffs, metarhyolites, metadacites and metatuffs, trachytes and metatrachytes, basalts, green slates and amphibolites; 8 - Pre-Variscan intrusives and intrusives of unknown age: granites and metagranites, metagranodiorites and orthogneisses; 9 - downslip fault, often geomorphologically significant 


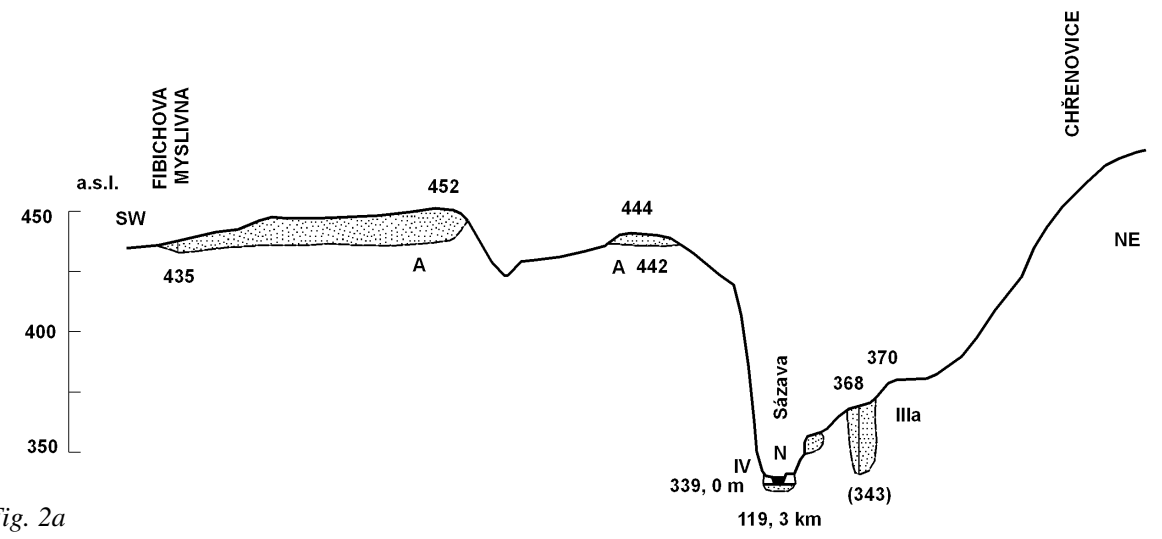

Fig. $2 b$
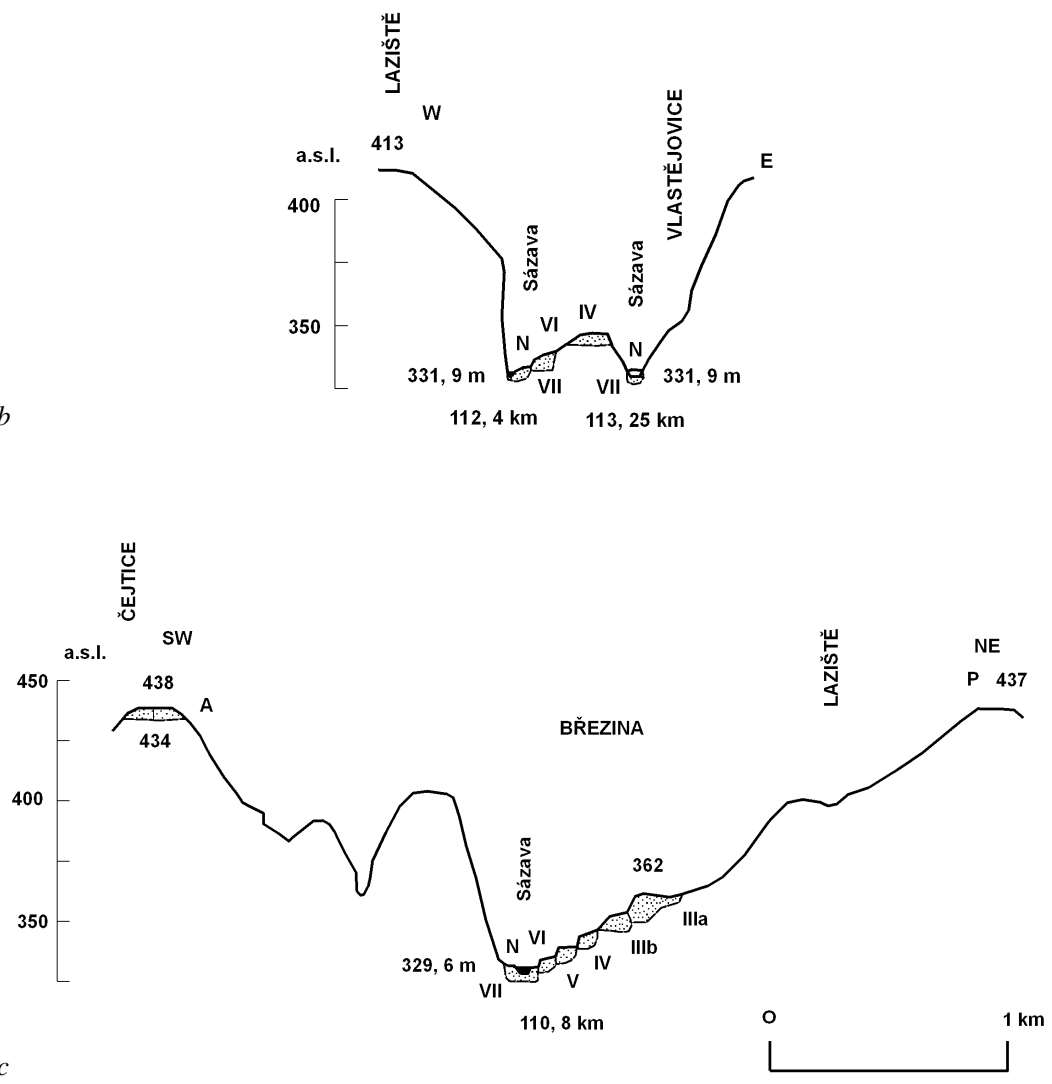

Fig. $2 c$

Fig. 2 Transverse profiles of the Sázava valley with river terraces and planation surfaces in the reach between river kilometres 119.3 and 110.8. Key: A, B - Neogene sediments, Ia-VII - Pleistocene terraces, $\mathrm{N}$ - Holocene floodplain, $\mathrm{P}$ - planation surface, oblique lines - slope sediments. These profiles in Figs 2-5 are 10 times exaggerated 


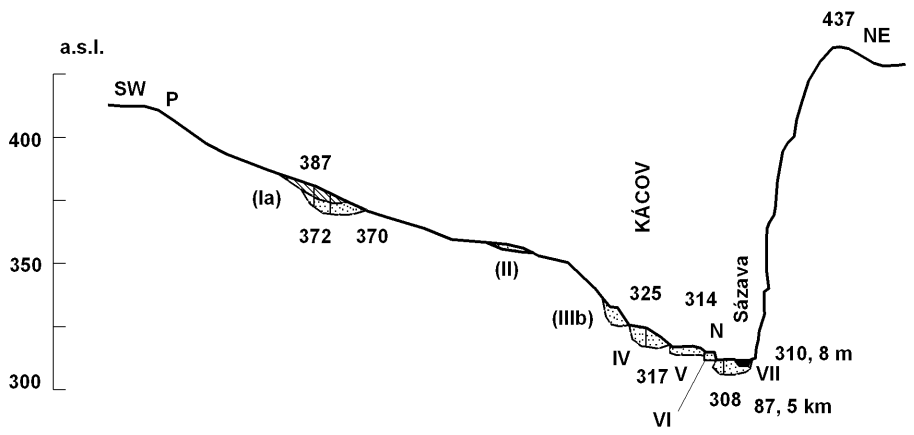

Fig. $3 a$

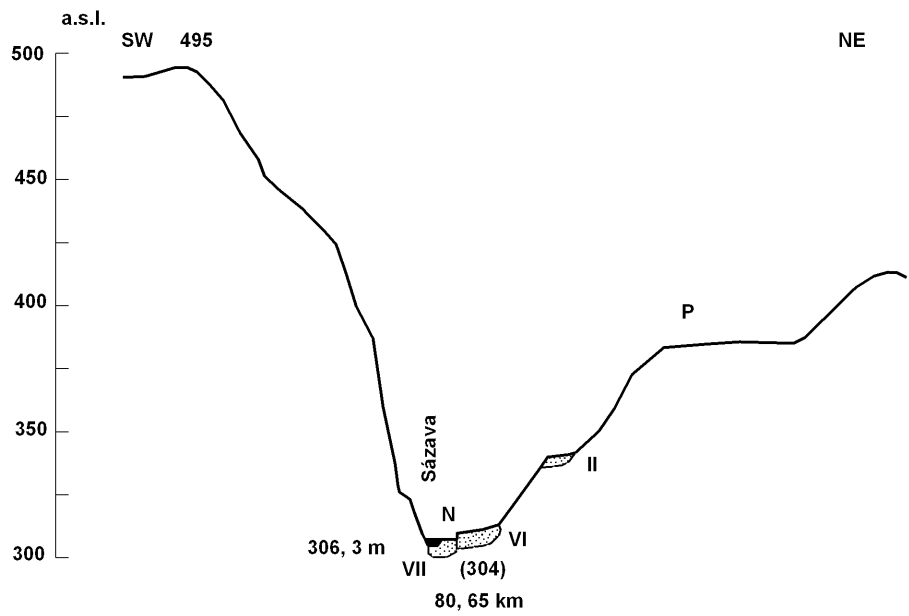

Fig. $3 b$

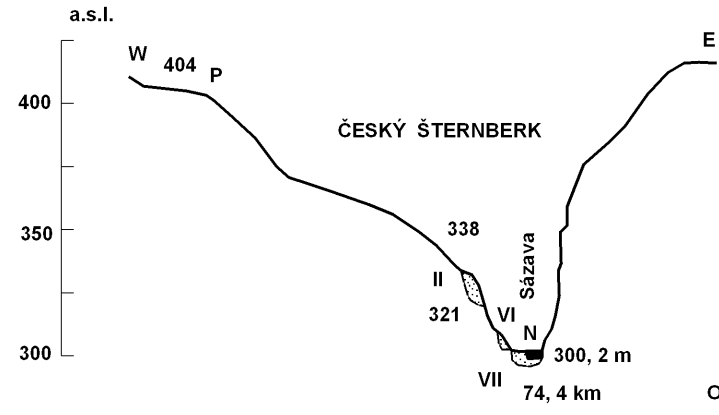

Fig. $3 c$

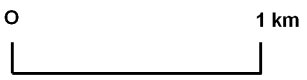

Fig. 3 Transverse profiles of the Sázava valley in the reach between river kilometres 87.5 and 74.4. Explanations are in Fig. 2 
Fig. $4 a$

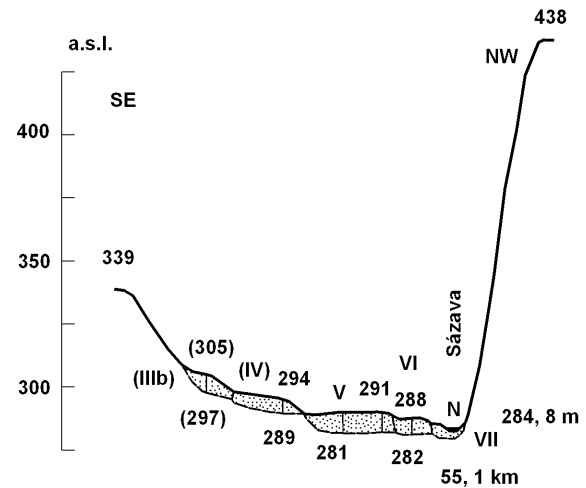

Fig. $4 b$
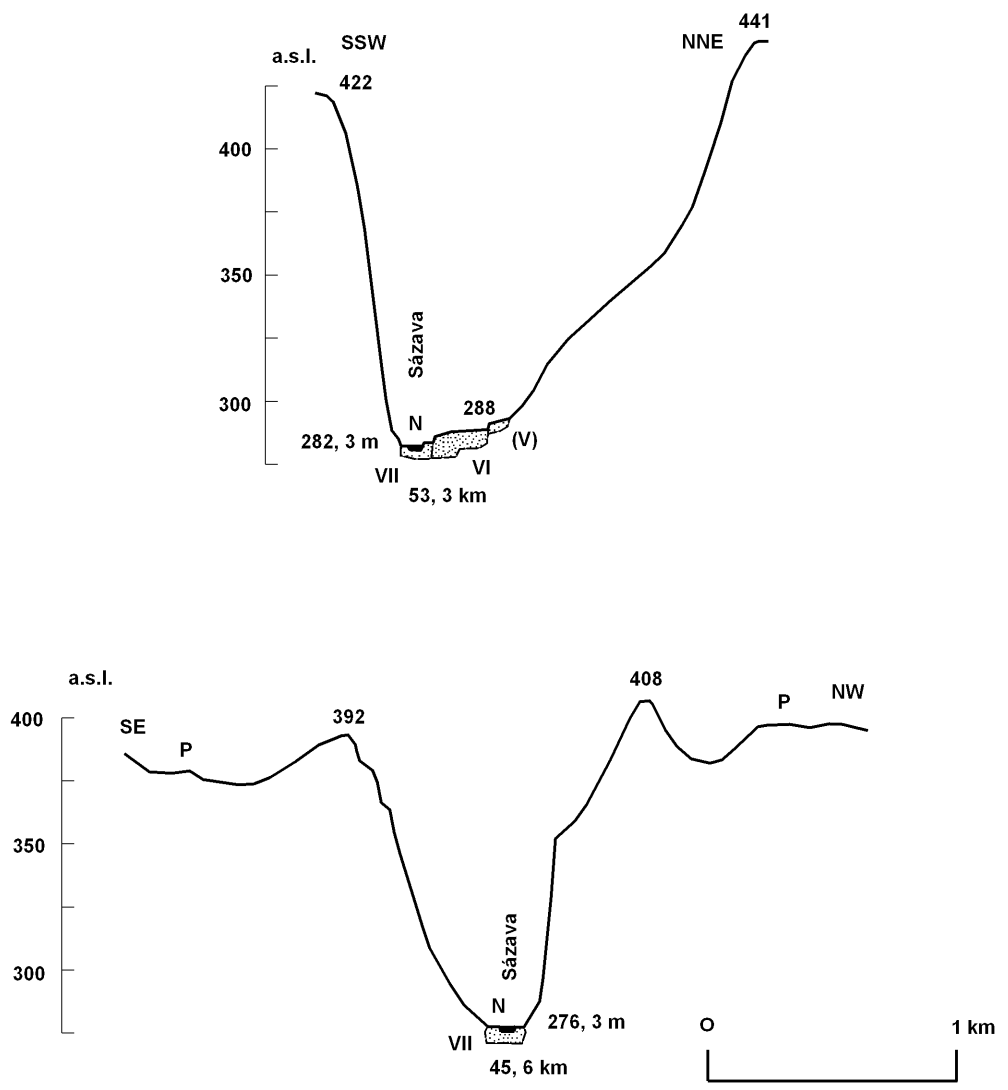

Fig. 4 Transverse profiles of the Sázava valley in the reach between river kilometres 55.1 and 45.6. Explanations are in Fig. 2 


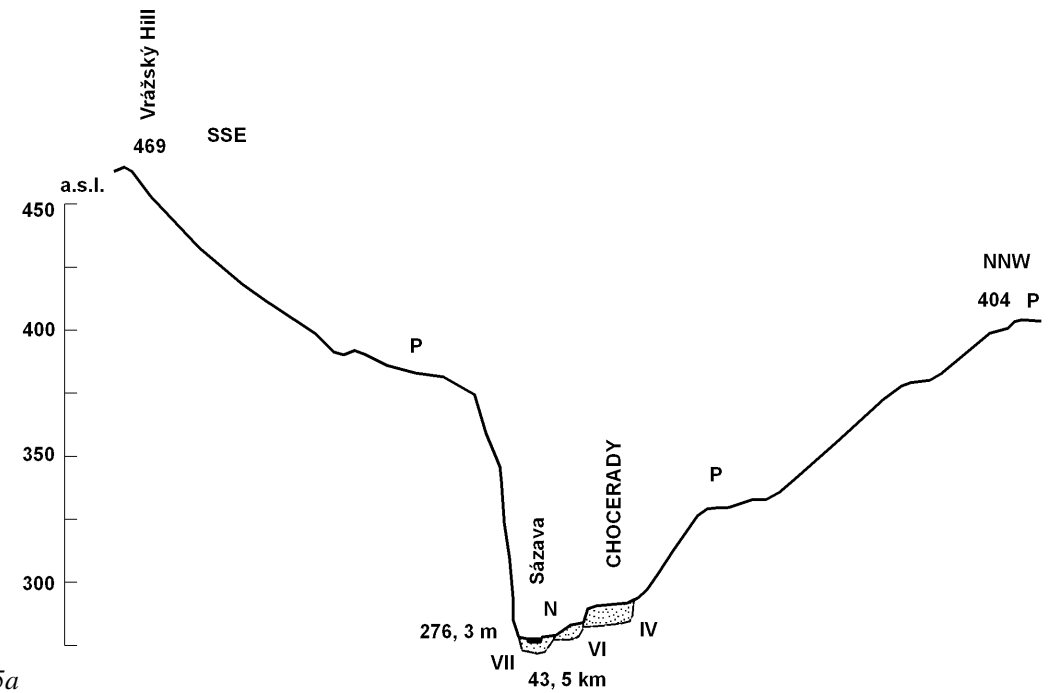

Fig. $5 a$

$43,5 \mathrm{~km}$

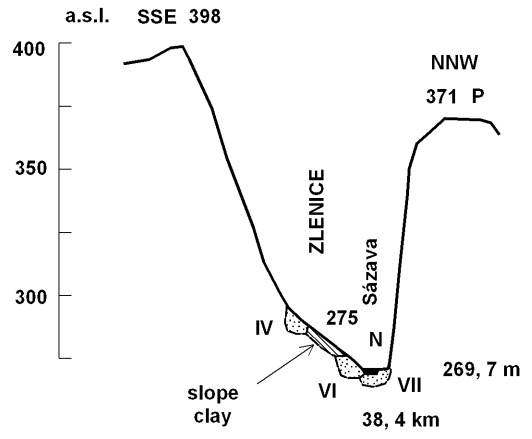

Fig. $5 b$

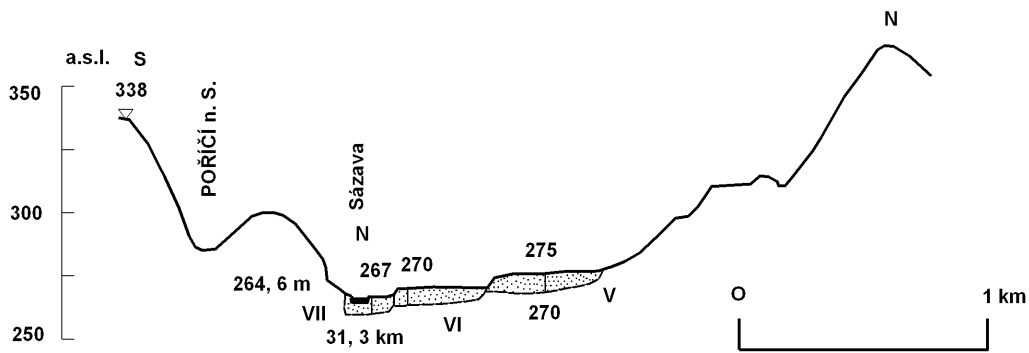

Fig. $5 c$

Fig. 5 Transverse profiles of the Sázava valley in the reach between river kilometres 43.5 and 31.3 . Explanations are in Fig. 2 


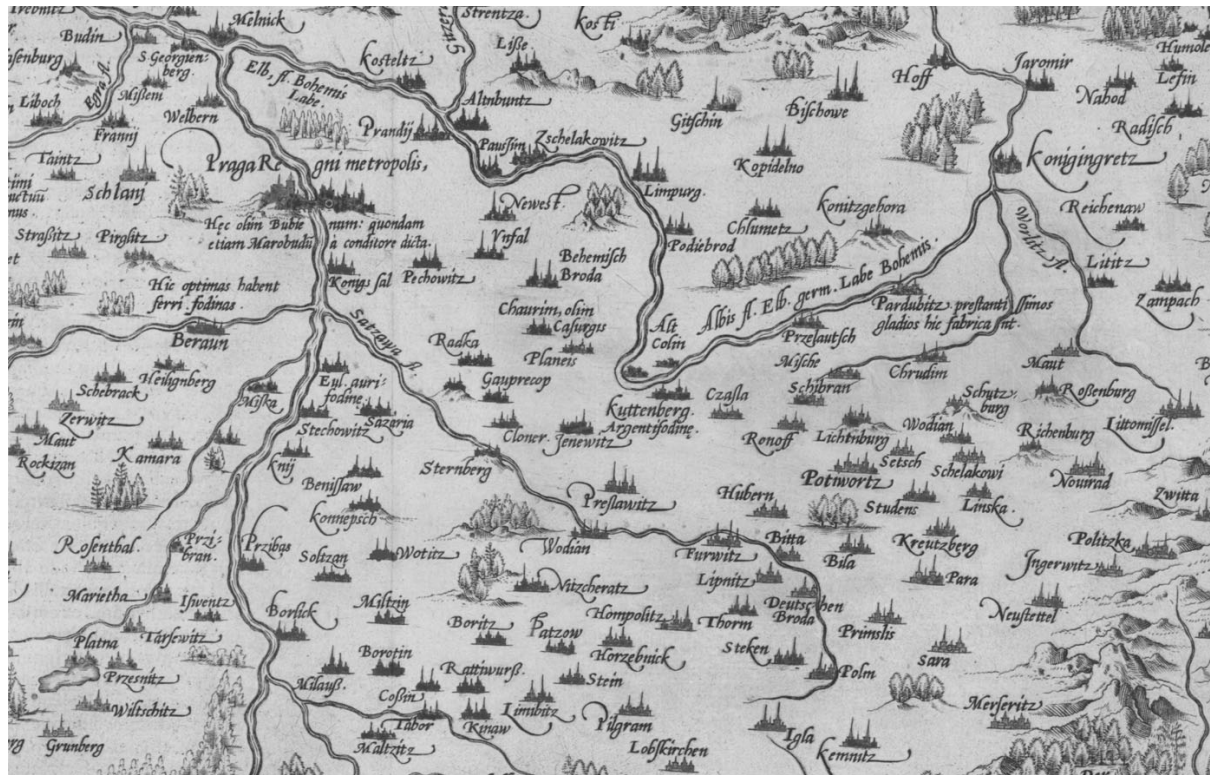

Photography 1 Position of the Sázava river at a part of the map "Regni Bohemiae descriptio" (Abraham Ortelius, Antverpy 1570). Remarkable is a lifelike sketch of main patterns of the river network in the middle Bohemia. They are conspicuous errors in drawings of confluence areas of the Sázava, Vltava and Berounka rivers in the $\mathrm{S}$ of Prague as well as the Orlice, Labe and Chrudimka rivers between the towns of Hradec Králové and Pardubice, and also of the source region of the Sázava river. This historical map $(53 \mathrm{~cm} \times 46 \mathrm{~cm})$ is a part of the "Teatrum orbis terrarum" by Abraham Ortelius. It is based on the Johann Criginger's map of Bohemia (1568) (Reproduction of the original map from the archives of the Map Collection of the Charles University in Prague Cartographical sources and historical data were provided by Petr Jánský)

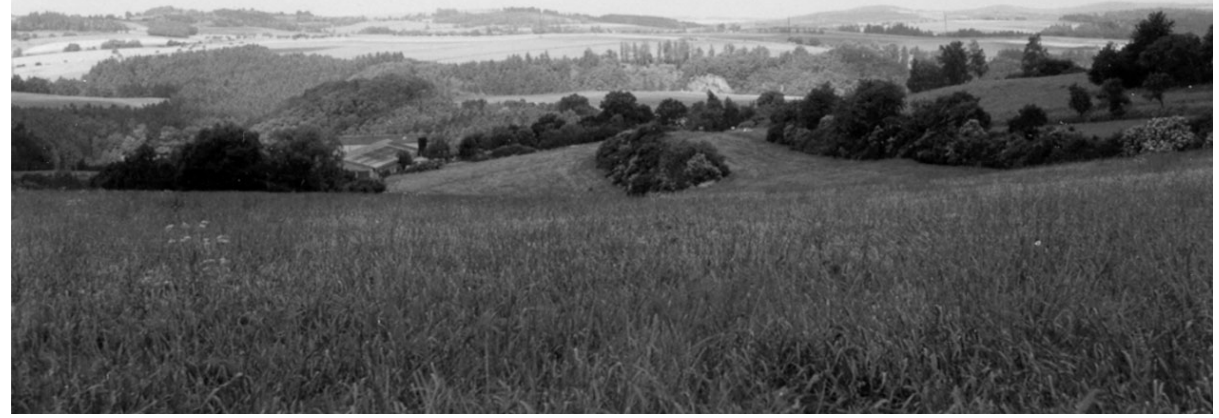

Photography 2 The large vale-shaped Sázava valley from the Upper Tertiary near Kácov, with pronounced plateaux of Pliocene planation surfaces of pediment type 


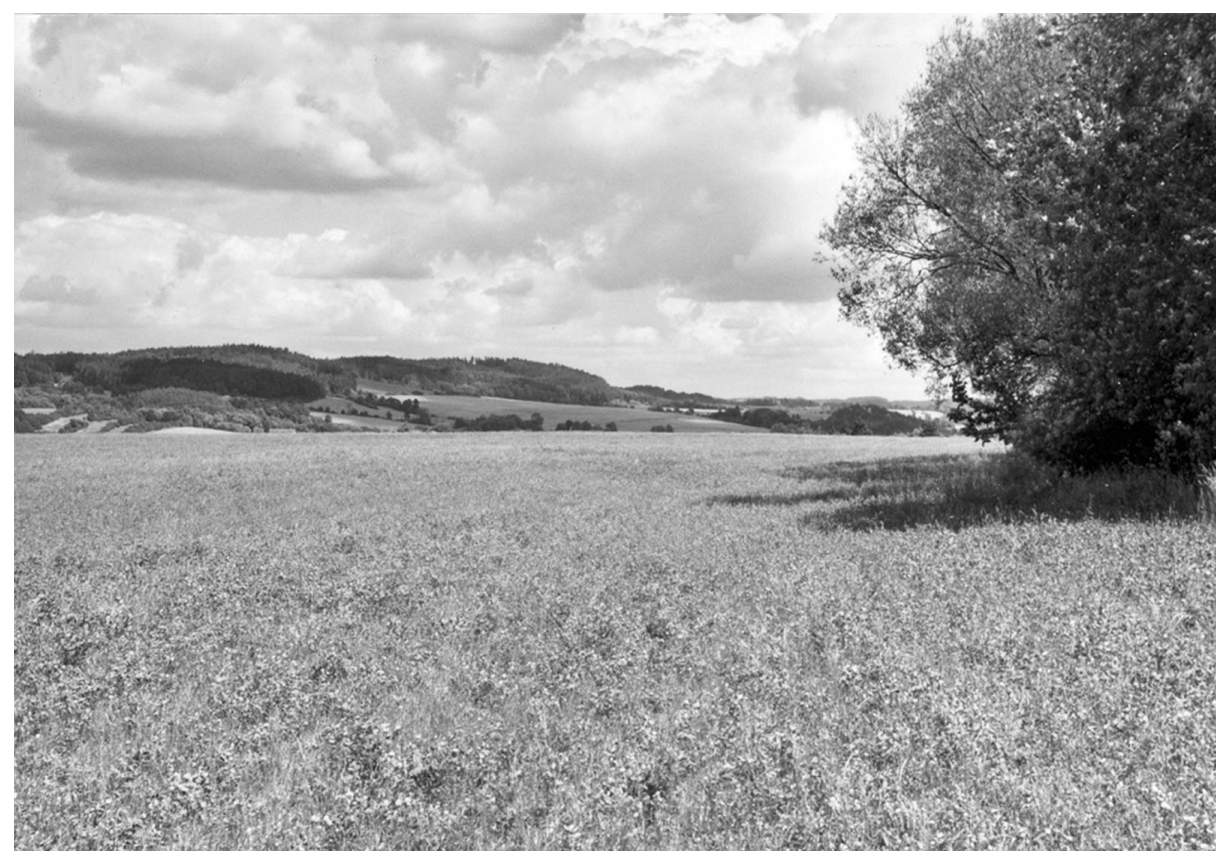

Photography 3 Plateau of the oldest Pleistocene river accumulation terrace I of the Sázava near Střechov

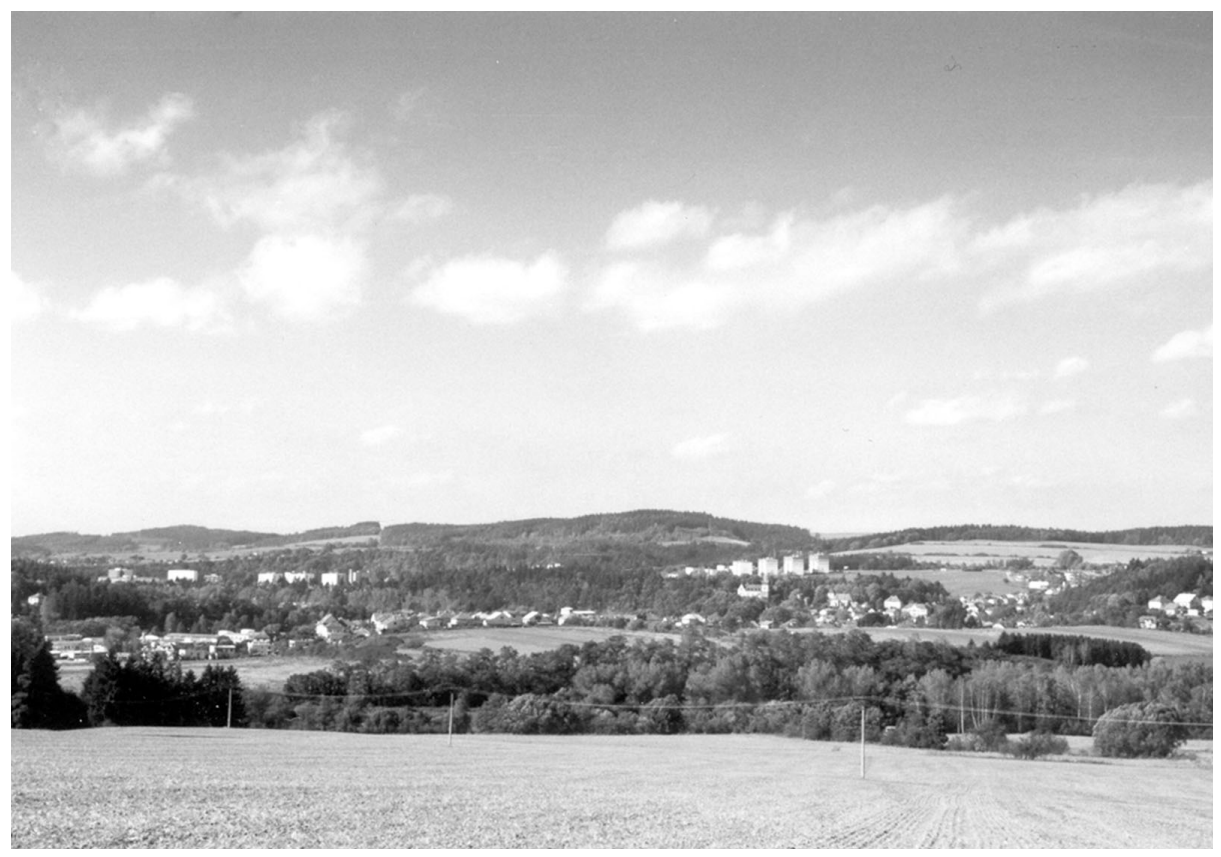

Photography 4 The large Sázava valley near Zruč nad Sázavou with plateaux of Middle Pleistocene terraces 


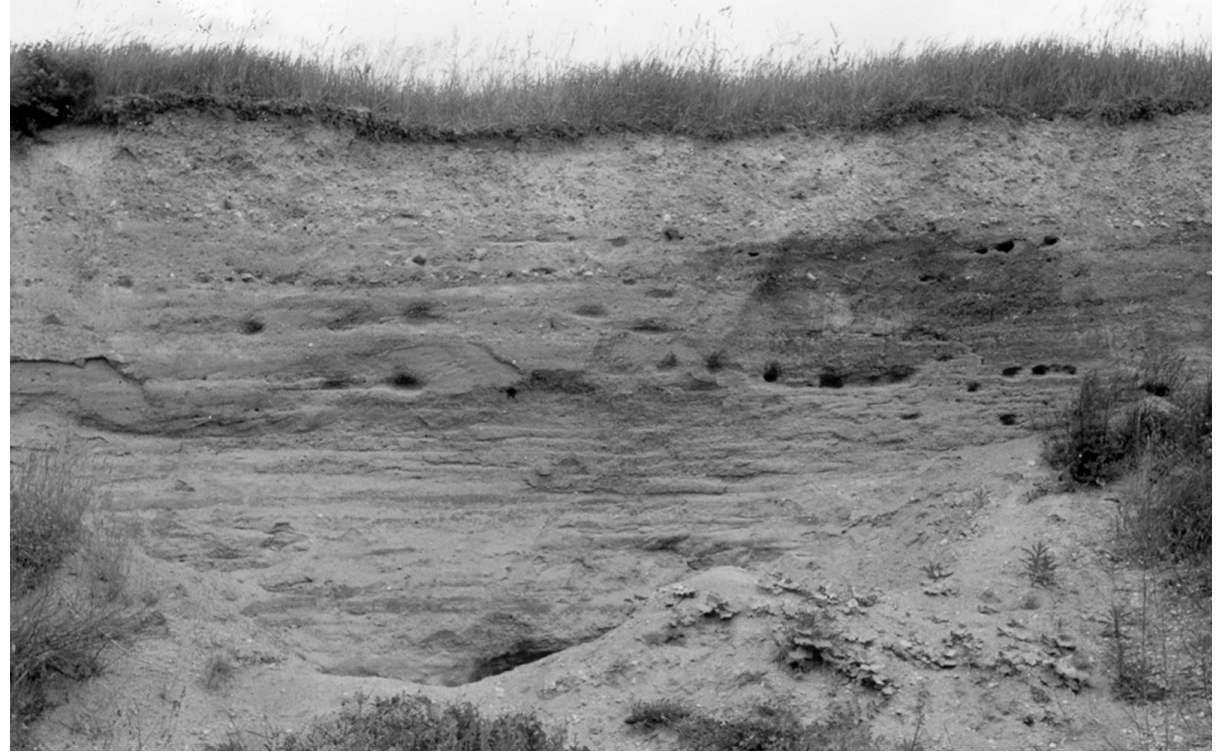

Photography 5 Compacted sands and tiny gravels of the Sázava terrace III near Buda

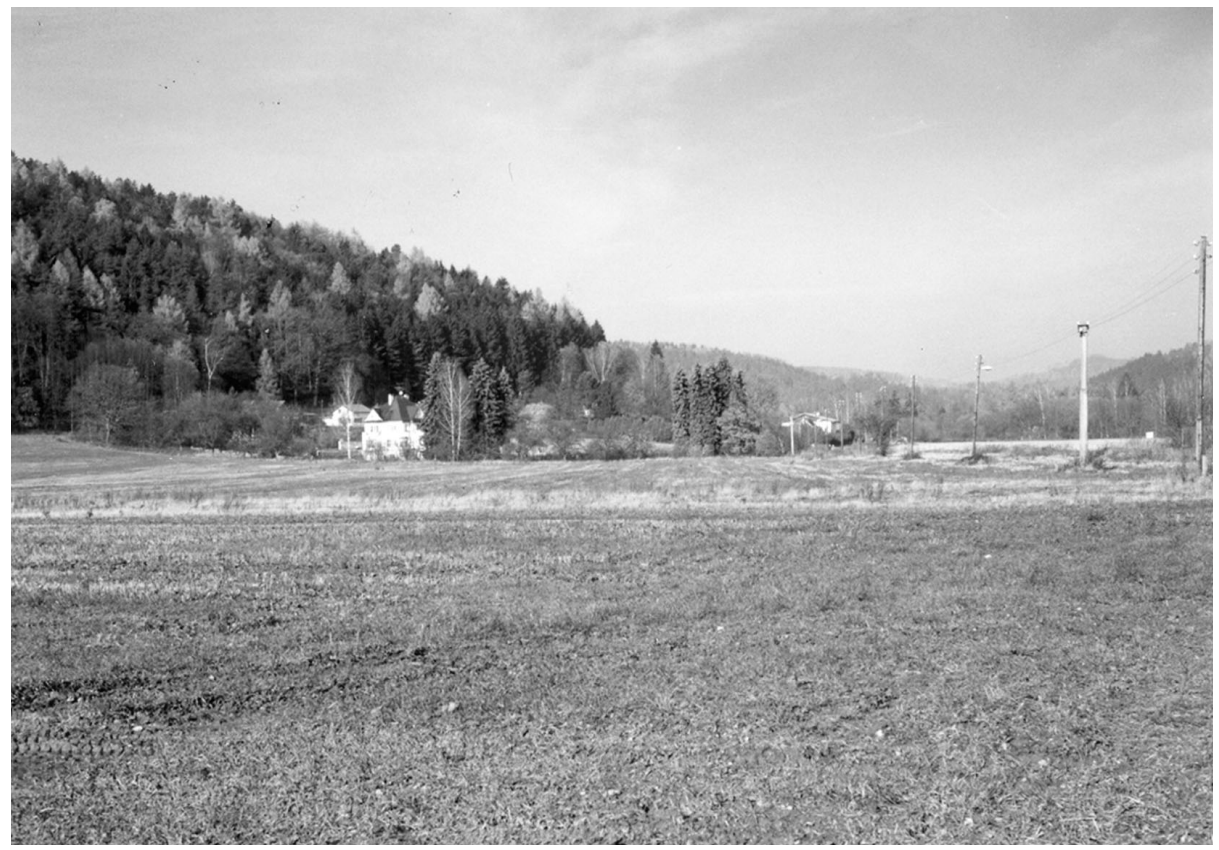

Photography 6 Plateau of the Sázava terrace VI on the left bank downstream from Pořičí nad Sázavou 


\section{Résumé}

\section{Morfostratigrafie teras řeky Sázavy v Českém masivu}

V práci jsou předloženy výsledky geomorfologického výzkumu řičních teras Sázavy. Tento terasový systém má velmi rozmanitou strukturu, která vznikala postupně působením specifických hydrodynamických procesů při vývoji údolí Sázavy v mladším kenozoiku. V údolí Sázavy byly zjištěny dvě úrovně neogenních říčních sedimentů a sedm stupňů terasových akumulací kvartérního stáŕí. Dnešní údolní dno střední části toku Sázavy leží vzhledem k nivě Vltavy ve zřetelně visuté poloze a na současnou úroveň bylo vyhloubeno převážně v době vzniku VI. terasy. Ve studii je také provedena chronostratigrafická korelace říčních teras Sázavy s terasami Vltavy a Labe. Podle aktuálního stratigrafického schématu kvartéru odpovídá celý systém teras Sázavy převážně období komplexu cromer po weichsel. Erozní fáze před akumulací I. terasy náleží v údolí Sázavy do závěru starého pleistocénu.

Prof. RNDr. Jan Kalvoda, DrSc. Department of Physical Geography and Geoecology

Charles University in Prague

Faculty of Science Albertov 6

12843 Prague 2

e-mail: kalvoda@natur.cuni.cz 